Growing Conversation: Understanding planning literacy in the City of Toronto

\author{
by \\ Katarzyna (Kasia) Kmiec \\ Juris Doctor, York University, 2013 \\ Bachelor of Commerce (Honours), Queens University, 2008 \\ A Major Research Paper \\ presented to Ryerson University \\ in partial fulfillment of the requirements for the degree of \\ Master of Planning \\ in \\ Urban Development \\ Toronto, Ontario, Canada, 2018
}

(C) Katarzyna (Kasia) Kmiec, 2018 


\section{Author's Declaration for Electronic Submission of a MRP}

I hereby declare that I am the sole author of this MRP. This is a true copy of the MRP, including any required final revisions.

I authorize Ryerson University to lend this MRP to other institutions or individuals for the purpose of scholarly research.

I further authorize Ryerson University to reproduce this MRP by photocopying or by other means, in total or in part, at the request of other institutions or individuals for the purpose of scholarly research.

I understand that my MRP may be made electronically available to the public. 


\title{
GROWING CONVERSATION: UNDERSTANDING PLANNING LITERACY IN THE CITY OF TORONTO
}

(C) Katarzyna (Kasia) Kmiec, 2018

Master of Planning

in

Urban Development

Ryerson University

\begin{abstract}
$\underline{\text { Abstract }}$
The City of Toronto's commitment to meaningful public engagement in planning processes is apparent throughout its many policies, plans and initiatives. However, despite consistent messaging that effective engagement leads to better outcomes and the many hours it spends on engagement efforts, the City Planning division has acknowledged that its approaches to community outreach are not always effective. City Planning’s 2014 “Growing Conversations” initiative revealed, among other findings, disparities in levels of planning knowledge between experts and stakeholders that lead to frustration and communication breakdowns. An outcome of this was to focus on improving the planning literacy levels of Torontonians.
\end{abstract}

However, Growing Conversations did not elaborate on how it intends to improve planning literacy, nor what it understands planning literacy to mean. By exploring the meaning of "planning literacy” and creating a diagnostic tool to measure it, this research paper seeks to stimulate meaningful discussion around what planning concepts everyday Toronto residents should be familiar with, help identify those concepts for which that is not the case, and consider how to act on that information.

\section{$\underline{\text { Key words }}$}

An article on urban planning in the City of Toronto, used the key words: planning literacy; public engagement; questionnaire; Toronto. 


\section{Acknowledgments}

It always takes a village to write research papers like this one. Thank you to my supervisor, Dr. Pamela Robinson, for your time, positive energy and support, not only in carrying out this research, but also during and even before this program.

A sincere thank you to all the people who participated in this research, in Toronto and beyond. I cannot stress enough how much I appreciate you taking time out of your days to provide the insights that have given this paper meaning. Anonymity requirements are keeping me from recognizing each of you by name, but I know who you all are, and am very grateful. I really enjoyed learning from each of you, and look forward to collaborating again in the field.

I would also like to thank my second reader, Antoine Belaieff, for also taking time out of his busy schedule to review and provide insightful reflections on my research. I very much appreciate your involvement in this project!

Finally, I am so grateful for my family, friends and partner/second reader in everything else, Anton, for tolerating my preoccupied self over the last two years. Your unconditional support means everything to me. 


\section{Table of Contents}

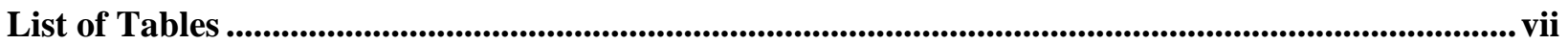

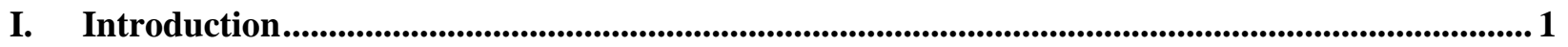

II. Literature review: What is planning literacy, and why is it relevant?.................................3

A. City Planning and public engagement in Toronto....................................................................... 3

(i) When, how and why do planners engage with the public?..................................................... 3

(ii) Emphases on public participation in Toronto planning policy, plans and initiatives............... 5

(iii) Challenges to effective public participation in Toronto............................................................ 8

(iv) Torontonians need to be more planning literate …............................................................ 9

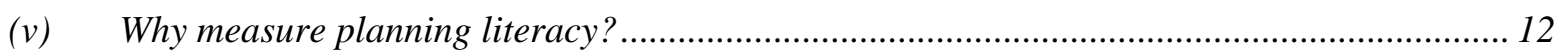

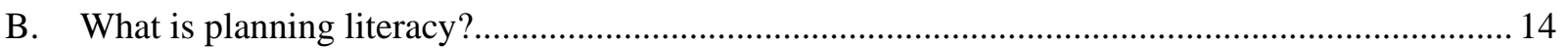

(i) Definitions of literacy in other domains ................................................................................ 14

(ii) Nutbeam's three levels of health literacy .............................................................................. 17

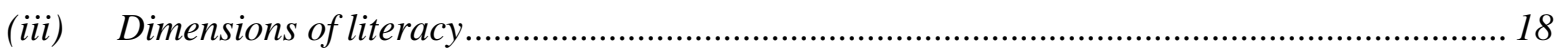

(iv) Other key takeaways from literacy research in other domains ............................................. 20

C. Measuring planning literacy: Looking to precedents................................................................ 21

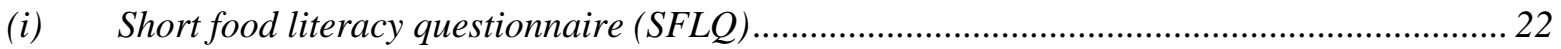

(ii) Financial literacy questionnaire (FinLQ) ........................................................................... 23

III. Method ......................................................................................................................................................... 26

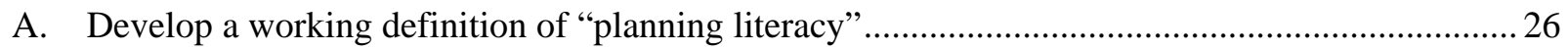

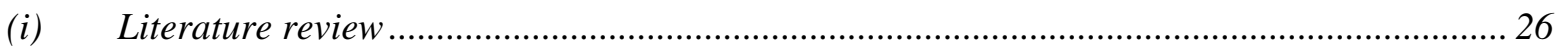

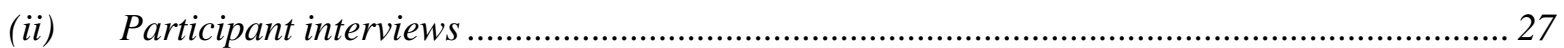

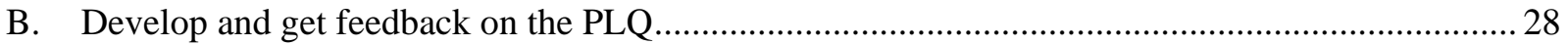

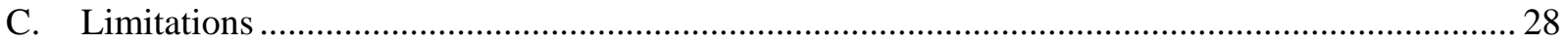

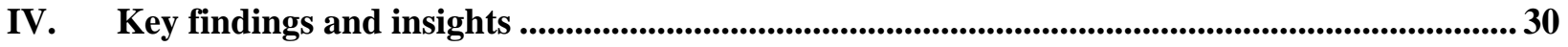

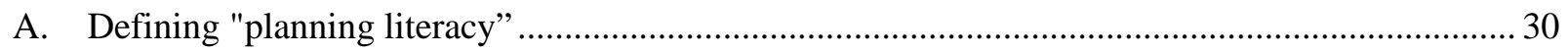

B. The relationship between planning literacy and democratic processes........................................ 34

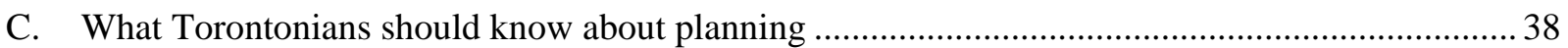

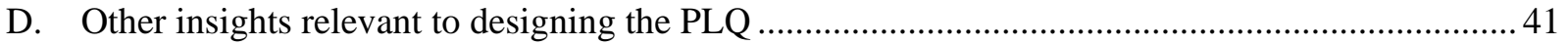

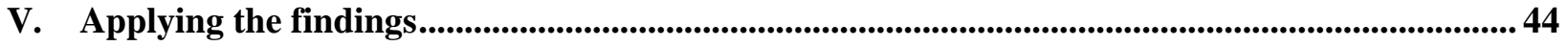

A. A proposed definition for planning literacy in Toronto .................................................................. 44

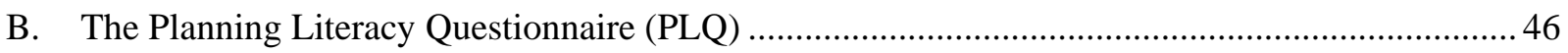

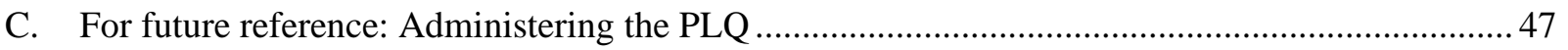

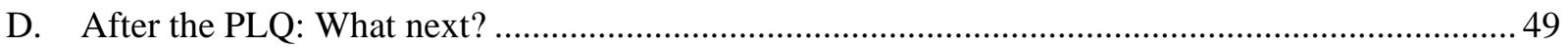

(i) Responding to low planning literacy levels.......................................................................... 49

(ii) The planning literacy continuum ........................................................................................... 50 


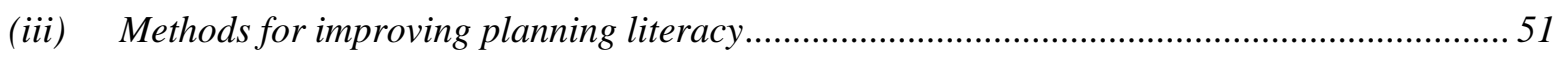

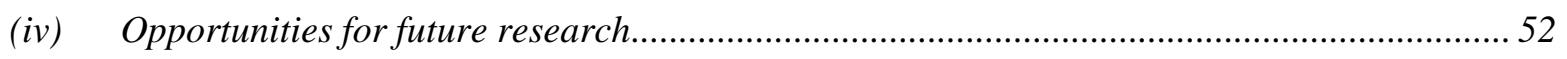

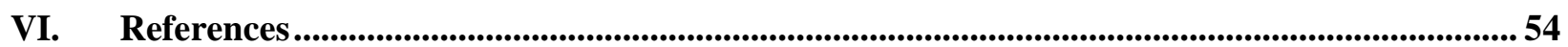

Appendix A - List of Participants Interviewed

Appendix B - Questions Asked in Interviews

Appendix C - Planning “Jargon”

Appendix D - Precedent Literacy Questionnaires

Appendix E - The Planning Literacy Questionnaire (PLQ) 


\section{$\underline{\text { List of Tables }}$}

Table 1 Examples of initiatives designed to improve planning literacy in Toronto .................................. 11

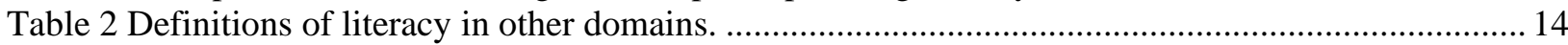

Table 3 Proposed forms of planning literacy and corresponding planning literacy themes ...................... 44

Table 4 Working definition of nutrition-specific health literacy (Krause et al., 2016)..........................D-1

Table 5 Final SFLQ with corresponding themes (Krause et al., 2016; Krause et al., 2018)...................D-1

Table 6 Participant demographic information (Krause et al., 2018) .................................................... D-2

Table 7 Four themes of financial literacy and corresponding core questions (Kempson, 2009) ...............

Table 8 OECD INFE (2011) FinLQ Core Questionnaire ................................................................... D-4 


\section{Introduction}

There is plenty to illustrate the City of Toronto City Planning division's pursuit of meaningful public engagement. Every year, City Planning undertakes thousands of hours of public engagement on a range of planning processes, from development applications, to studies and plans, to other neighbourhood and city-wide priorities (Toronto City Planning, n.d.-a). It often goes above and beyond the minimum consultation requirements set out under provincial legislation and the City of Toronto’s Official Plan (n.d.-a). In its current divisional strategic plan, City Planning committed itself to "continually working to broaden meaningful participation in city building” and to achieving effective, ongoing two-way communication with city building stakeholders (Toronto City Planning, 2013, 61).

City Planning recognizes that improving public engagement is a perpetual process, and has done important work to acknowledge, understand and address constraints to effective engagement in the City. Through its “Growing Conversations” initiative, City Planning consulted with close to 1,000 residents and stakeholders on how to improve public engagement in local planning processes, revealing frustrated residents who felt their input was not being used, found it hard to access planning-related information, and were in many cases from under-represented groups that included newcomers, renters and youth. This work helped City Planning identify challenges to effective engagement and develop principles for city planners to be guided by in future engagement efforts (Toronto City Planning, n.d-b).

Among other challenges, Growing Conversations put a spotlight on the concept of "planning literacy”, noting how a lack of understanding of Ontario's complex planning system can be a barrier to participation, and proposing to expand City Planning’s efforts to “build Torontonians’ understanding of planning concepts, principles and processes” (Toronto City Planning, n.d-b). One of the resulting action items seeks to “improve the public’s understanding of planning issues, with clear objectives to improve planning literacy” (n.d-b). 
Despite these clear objectives, Growing Conversations does not elaborate on what it means by “planning literacy”, and how City Planning should go about improving it. Which specific planning concepts, principles and processes should Torontonians know? What kind of familiarity does City Planning (or any practicing planner who regularly engages with members of the public, for that matter) expect a typical resident to have of Ontario's complex planning system? If certain key concepts, principles and processes are found to be particularly challenging for Torontonians, how should City Planning respond? And when City Planning does respond, how will it know that its efforts are working? Conversations with sources from City Planning suggest that the division does not have very developed positions on these questions, which are important to address if it wishes to achieve its planning literacy objectives.

Drawing on literature, local policy and interviews with participants with a range of experiences in public engagement and civic education across Canada and the United States, this research paper unpacks the term “planning literacy”, proposes a working definition for planning literacy in the Toronto context, and offers a diagnostic tool that City Planning can use to measure and benchmark public planning literacy levels across the City. Above all, it seeks to stimulate discussion around what everyday Toronto residents should know about planning, and how to respond to findings suggesting that Torontonians do not know what planners expect them to. 


\section{Literature review: What is planning literacy, and why is it relevant?}

\section{A. City Planning and public engagement in Toronto}

(i) When, how and why do planners engage with the public?

Public engagement has not always been a priority on planners’ agendas. Traditional rationalcomprehensive or "blueprint" models of planning that dominated the early part of the $20^{\text {th }}$ century viewed planners as "pre-eminent” and “omnipotent” beings who could methodically apply science and logic to reach some collectively-beneficial end state (Lane, 2005). Planning was treated as an apolitical exercise, and the public interest was taken as a given and a single, unified concept (2005). As late as the 1960s, planning journals referred to planners to as "urban scientists” with "all the characteristics of the physical and biological and space scientists”, perpetuating the rational-comprehensive view of planners as technicians (Whittemore, 2015). Local communities were not invited to contribute to planning decisions in those days, other than during election time; in fact, "providing citizens a voice in determining the ends and means of planning was contrary to the basic conceptions of blueprint planning” (Lane, 2005, 289).

Around the same time as planning journals were calling planners urban scientists, however, tensions were rising, and rational-comprehensive planning faced growing criticism, both from the planning community and the broader public. Coincident with other social movements, such as the anti-war, environmental, civil rights and women’s rights movements, people began to speak up. They opposed "urban renewal” projects and freeway construction programs, and expressed concern with planning processes (Ward Mather, 2014). Rational-comprehensive planning models were criticized for a number of reasons, but particularly for failing to meaningfully listen to the very communities that they proposed to change, and for disregarding the interests of vulnerable stakeholders (Lane, 2005). As demand for local participation increased, more progressive, equity-oriented models such as advocacy planning (e.g. Davidoff, 1965) and participatory planning (e.g. Healey, 1992; Armour, 1991; Arnstein, 1969; Forester, 1989) emerged. In 
contrast to rational comprehensive planning, these schools of thought appreciated that society is made up of many different actors with as many different interests and power dynamics, and considered public participation “a fundamental element of planning and decision-making” (Lane, 2005, 296).

While elements of rational-comprehensive planning continue to exist in today's approaches to decisionmaking in planning, ${ }^{1}$ public participation is clearly valued and actively pursued in modern Western societies. Many planners, public officials and citizens now advocate public participation as a "practical, judicious and ethical imperative” (Nabatchi \& Leighninger, 2015, 165). There are many reasons for this dedication to public participation, including (Bedford, Clark, \& Harrison, 2002, 312; Innes and Booher, 2004, 422):

(1) A belief that everyone should know they can influence the shape of their community;

(2) For decision makers to find out what the public's preferences are, so these can play a part in their decisions;

(3) To improve decisions by incorporating citizens' local knowledge into the calculus;

(4) To advance fairness and justice by providing opportunities for participation to systemically disadvantaged groups;

(5) To get legitimacy for public decisions; and

(6) To fulfill legislative requirements.

These reasons align with what City Planning suggests are its own reasons for engaging with the public, which are to build capacity and inform participation, inform planning processes and facilitate city building (Toronto City Planning, n.d.-a, 3).

\footnotetext{
${ }^{1}$ For example, in Ontario, the scientific logic of that model is apparent in the Planning Act (Ontario), the legislation that sets out ground rules for land-use planning in the province. Among other requirements, it requires cities to create, follow and regularly update comprehensive planning frameworks through official plans. Rational planning is also reflected in the provincial Environmental Assessment Act (Ontario), which requires proponents to consider potential environmental effects before beginning major infrastructure projects by following a complicated, systematic sequence of steps.
} 
(ii) Emphases on public participation in Toronto planning policy, plans and initiatives

"Public engagement is one of the main tools planners use to make sure the city's diverse perspectives and priorities are reflected in their work, and through public engagement people can have a real and meaningful influence on planning and on Toronto's future."

(Toronto City Planning, 2015, Discussion Guide Appendix)

The City of Toronto’s broad commitment to achieving meaningful public engagement is manifested throughout its many planning policies, plans and initiatives. The City of Toronto Official Plan, the policy framework that directs and manages physical change in the City over a period of 30 years, proclaims an inspiring city-building vision of "creating an attractive and safe city that evokes pride, passion and a sense of belonging - a city where people of all ages and abilities can enjoy a good quality of life” (Section 1). The Official Plan serves not only as a statement of intent and guidance, but also as the legal backbone of a wide range of municipal activities, including planning and approval of public works (e.g. roads, parks and community facilities), development of planning tools (e.g. comprehensive zoning by-laws), and review and approval of development applications (Gladki Planning Associates, Hemson Consulting, \& Studio Jay Wall, 2017).

The Official Plan sets out principles “for a successful Toronto", one of which envisions a city of "leaders and stewards” where "individuals and communities actively participate in decisions affecting them, [...] people are inspired to become involved in affecting positive change, [...] and people are engaged and invested in city living and civic life” (Section 2). The Plan broadly states that its implementation "needs the participation of all segments and sectors of the City” (Section 2) and specifically identifies various contexts where community consultation must be undertaken. ${ }^{2}$

\footnotetext{
${ }^{2}$ Examples include: where new zoning by-laws and design guidelines for areas designated "Avenues” are to be created (Policy 2.2.3.2), where significant intensification of land adjacent to areas designated "Neighbourhood" or "Apartment Neighbourhood" is proposed and requires new policies (Policy 2.3.1.3), or where new secondary plans are being developed (Policy 5.2.1.2).
} 
Section 5.5 of the Official Plan acknowledges the consultation requirements under the Planning Act, ${ }^{3}$ noting that municipalities may require more than the prescribed minimum, and encourages (though does not require) developers to consult with ward councilors, City staff and local communities prior to formally submitting planning applications. Section 5.5.1 sets out expectations for a "fair, open and accessible public process for amending, implementing and reviewing” the Official Plan, indicating that such a process will be achieved by, among other things (emphasis added):

(a) encouraging participation by all segments of the population, recognizing the ethno-racial diversity of the community and with special consideration to the needs of individuals of all ages and abilities;

(b) promoting community awareness of planning issues and decisions, through use of clear, understandable language and employing innovative processes to inform the public, including the use of traditional and electronic media; and

(c) providing adequate and various opportunities for those affected by planning decisions to be informed and contribute to planning processes, including (i) encouraging preapplication community consultation [and] (ii) holding at least one community meeting in the affected area, in addition to the minimum statutory meeting requirements of the Planning Act, for proposed Official Plan and/or Zoning By-law amendments prior to approval $[\ldots]$

City Planning’s internal strategic plan sets out the division's objectives of facilitating "broader, more meaningful engagement within and outside City Hall to respond to the pace and complexity of change in the city” (Toronto City Planning, 2013, 21) and ensuring “effective ongoing two-way communication” within and between the division and outside City Hall in delivering the key messages of the Official Plan

\footnotetext{
${ }^{3}$ The Planning Act (Ontario) legally requires a minimum number of public meetings and open houses to be held at certain points throughout the development approvals process, and for affected residents to receive notice of opportunities to attend.
} 
(Toronto City Planning, 2013, 29). Notably, the Strategic Plan calls on the division to "take the Official Plan to the community", turn it into "the construct within which the community is able to discuss and analyze city building issues and proposals” and provide "clear messaging for the City Planning division at public meetings by making the division's role in city building known in a consistent and straightforward manner” (Toronto City Planning, 2013, 61).

The broader, citywide 2013-2018 City of Toronto Strategic Actions plan also seeks to ensure that "individuals and groups have a collective sense of belonging and contributing to the city, and have the capacity to participate in the city’s social, political, economic and cultural life” (City of Toronto, 2013, 18). That plan explicitly identifies public participation as “an integral part of the City’s decision-making processes” in its mission statement (City of Toronto, 2013, 3), and proposes strategic actions that, among other things, aim to enhance the City's capacity to inform, engage and consult the public (e.g. Strategic Action \#14 Engage the Public) (City of Toronto, 2013, 26).

Other plans, strategies and initiatives convey similar messages around the City's commitment to public engagement in planning and civic matters. Every year, City Planning regularly exceeds the legislative minimums set out by the Planning Act, undertaking thousands of hours of public engagement through a wide range of media, such as through community meetings, open houses, focus groups, advisory groups, specialized online surveys and tools, and ad hoc discussions, in as it engages in four general contexts: when it receives a development application; when a neighbourhood-based planning process is initiated; when a broader city-wide planning process or special study is initiated; and when it wants to talk about city building (Toronto City Planning, 2015, 7-8; Toronto City Planning, n.d.-a, 3).

At the end of the day, regardless of how aspirational its policies are and how many hours it spends with local communities, City Planning must recognize that its engagement activities will be of limited use if participants are not speaking the same language as the organizers. 
"The more you learn about a topic, the harder it is to remember what it was like to be a novice. To some extent we are all living in a 'planning bubble'."

(Biggs, 2016)

City Planning's ambitions to improve dialogue and engagement with the public to advance the objectives of the Official Plan clearly form an important part of its mandate and activities. However, despite consistent messaging that effective engagement leads to outcomes that better reflect the vision and values of local communities, and the many hours it clocks doing public engagement, City Planning has admitted that its approaches to community outreach have not always been effective.

For example, there appears to be a general lack of public awareness of the Official Plan. The 2013-2018 City Planning Strategic Plan found (through an unknown method) that despite the benefit of a "strong, contemporary policy framework” provided by the Official Plan, there was an "inconsistent acknowledgment of this strong policy direction”, due to, among other reasons, a "lack of understanding... by some to fully embrace the policy themes for the whole city” (Toronto City Planning, 2013, 33). Although "the Official Plan has provided a clearly articulated Vision for the City of Toronto for more than a decade, the knowledge and integration of that Vision is not widespread” (Toronto City Planning, 2013, 54). City Planning's objectives for the 2013-2018 period included raising community awareness of the Official Plan and the division's role in implementing it, and turning the Plan into "the construct within which the community is able to discuss and analyze city building issues and proposals” (Action 30). The division also realized that it has not been reaching all the audiences it should be, including newcomers, lower-income residents and youth, and that as a result, people whose futures are strongly impacted by planning are not influencing as much as they should (Toronto City Planning, 2015, Discussion Guide Appendix). 
Roadblocks to effective public engagement in planning have been extensively studied by academics and practitioners alike (and by City Planning, as described in the next section), and this paper does not suggest to exhaustively identify or analyze them all. However, expecting too much time, empathy and planning knowledge from participants are common mistakes that hamper public outreach processes (Biggs, 2016). Other roadblocks to effective engagement include limited time and resources (both on part of citizens and planning departments), lack of opportunity for genuine dialogue between competing stakeholders, overlystructured meeting formats, poorly-designed engagement materials, and (particularly relevant to a discussion on planning literacy) knowledge gaps between experts and stakeholders (Cohen, Wiek, Kay, \& Harlow, 2015; Innes \& Booher, 2004; Lao, 2016).

(iv) Torontonians need to be more planning literate

In 2014, City Planning launched Growing Conversations, an initiative designed to improve the relationship between City Planning, residents and other stakeholders through better community engagement, with the ultimate goal of making Toronto "the most engaged city in North America" (Toronto City Planning, n.d.-a, 3). With input received from online consultations, resident association roundtables, and staff and stakeholder workshops, City Planning identified local challenges (“Opportunities for Change”), developed nine “Principles for Effective Engagement” to help guide staff in the planning and execution of engagement processes and events, and committed to creating a new “Engagement Action Plan” for City Planning (informed by a youth engagement strategy and a forthcoming newcomer engagement strategy).

Growing Conversations shows that City Planning is aware that a necessary part of engagement includes ensuring that "residents and stakeholders are equipped with the right information that will allow them to engage meaningfully in the planning process” (Toronto City Planning, n.d.-a, 3). Consistent with the literature, consultations revealed that where levels of planning knowledge are disparate between experts 
and stakeholders, participants feel frustrated and the process is less effective, thus suggesting that low planning literacy can derail engagement efforts - and that this is very much an issue in the City of Toronto.

For example, a residents' association roundtable discussion held in Scarborough noted that "accessibility, both in terms of language and process, can be a barrier to participation”, and that it can be "difficult for people with English as a second language to communicate with planning” (Toronto City Planning, 2014D). A similar discussion in North York suggested that "lack of understanding of the planning process on part of the public" is one of many barriers to proper engagement, and that "the existing community planning process suffers simultaneously from a lack of iteration in community engagement and a level of complexity that makes it difficult for people to navigate it” (Toronto City Planning, 2014E). In Etobicoke, participants proposed that "more, better educational programs should be developed to help the public understand the planning process” (Toronto City Planning, 2014F). A similar downtown-based roundtable found that there is a lack of knowledge/understanding around the planning process, and noted that understanding planning issues requires a considerable time commitment (Toronto City Planning, 2014G).

These findings led to the following Opportunity for Change, further highlighting why planning literacy is important:

The planning process in Ontario is complex and difficult to navigate, and this can be intimidating to many people, creating a barrier to participation. City Planning currently works to build planning literacy through initiatives such as Planning 101 meetings and World Town Planning Day outreach, as well through easy-to-understand informational pamphlets. Expanding our efforts to build Torontonians' understanding of planning concepts, principles and processes will go a long way towards more inclusive engagement, and more relevant, accessible communication (Toronto City Planning, n.d.-b). 
A related Principle for Effective Engagement was developed to guide planners to work toward improving planning literacy:

Educational: Planning processes should seek to improve the public's understanding of planning issues, with clear objectives to improve planning literacy (Toronto City Planning, n.d.-b).

Numerous initiatives and programs in the City of Toronto seek to improve citizens' planning literacy and levels of civic engagement, though the term "planning literacy” rarely comes up. Examples of such initiatives, which are mostly spearheaded by City Planning and by non-profit organizations, are set out in

\section{Table 1.}

Table 1 Examples of initiatives designed to improve planning literacy in Toronto

\begin{tabular}{|c|c|c|}
\hline $\begin{array}{c}\text { Planners in Public Spaces (PiPS) } \\
\text { City Planning } \\
\text { City planners set up temporary stations } \\
\text { in public spaces to provide } \\
\text { opportunities for the public to speak } \\
\text { with them, one-on-one, on whatever } \\
\text { city building issues are important to } \\
\text { them. } \\
\text { (City of Toronto, 2017b) }\end{array}$ & $\begin{array}{l}\text { TOcore Avatars } \\
\text { City Planning } \\
\text { A set of fictional profiles based on real } \\
\text { data, created by City Planning for its } \\
\text { TOcore secondary plan study. The } \\
\text { avatars attempt to help relate planning } \\
\text { issues to people's lived experiences in } \\
\text { concrete ways. } \\
\text { (Toronto City Planning, 2017b) }\end{array}$ & $\begin{array}{c}\text { World Town Planning Day } \\
\text { City Planning } \\
\text { Planners in Toronto and around the } \\
\text { world engage in activities on or around } \\
\text { November 8th (World Town Planning } \\
\text { Day) to raise awareness of the } \\
\text { importance of planning in their } \\
\text { communities. } \\
\text { (Ontario Professional Planners Institute, } \\
\text { n.d.-b) }\end{array}$ \\
\hline $\begin{array}{c}\text { Planning } 101 \text { Presentations } \\
\text { City Planning } \\
\text { City Planning occasionally collaborates } \\
\text { with schools and other interested } \\
\text { organizations to give "Planning 101" } \\
\text { presentations that teach the basics of } \\
\text { planning. } \\
\text { (Participant \#6, 2018) }\end{array}$ & $\begin{array}{c}\text { Jane's Walks } \\
\text { Non-profit organization } \\
\text { Jane's Walks are free citizen-led } \\
\text { walking tours that encourage people to } \\
\text { share stories about their } \\
\text { neighbourhoods, discover unseen } \\
\text { aspects of their communities, and aim } \\
\text { to improve urban literacy. They take } \\
\text { place in Toronto and beyond. } \\
\text { (JanesWalk, n.d.) }\end{array}$ & $\begin{array}{c}\text { Maximum City } \\
\text { Incorporated social enterprise } \\
\text { Maximum City works with schools to } \\
\text { train teachers to deliver its hands-on } \\
\text { city-building and environmental } \\
\text { challenges for students. } \\
\text { (Participant } \# 12,2018 \text { ) }\end{array}$ \\
\hline $\begin{array}{c}\text { Toronto Planning Review Panel } \\
\text { (TPRP) } \\
\text { City Planning } \\
\text { An advisory body made up of residents } \\
\text { selected through a randomized process. } \\
\text { The TPRP provides input on major } \\
\text { planning initiatives. Educational } \\
\text { materials created for the TPRP are } \\
\text { publicly available online. } \\
\text { (Toronto City Planning, 2017a) }\end{array}$ & $\begin{array}{c}\text { City Planning informative pamphlets } \\
\text { City Planning } \\
\text { City Planning created a series of } \\
\text { informative pamphlets to teach } \\
\text { interested citizens about planning } \\
\text { initiatives and processes, such as the } \\
\text { Committee of Adjustment, Growing } \\
\text { Conversations and the Youth } \\
\text { Engagement Strategy. } \\
\text { (Available from City Planning) }\end{array}$ & $\begin{array}{c}\text { The Planning Clinic (TPC) } \\
\text { Non-profit organization } \\
\text { TPC's mission is to improve planning } \\
\text { literacy in Toronto. The organization is } \\
\text { volunteer-run and provides } \\
\text { communities with planning-related } \\
\text { research, education and consultation } \\
\text { services. } \\
\text { (The Planning Clinic, n.d.) }\end{array}$ \\
\hline
\end{tabular}




\begin{tabular}{|c|c|c|}
\hline $\begin{array}{l}\text { Street Level films } \\
\text { City Planning } \\
\text { In 2018, City Planning released the first } \\
\text { of its "Street Level” film series on } \\
\text { Youtube and social media. The series } \\
\text { aims to teach the public about the key } \\
\text { city building role City Planners play in } \\
\text { the development review process. } \\
\text { (Toronto City Planning, 2018) }\end{array}$ & $\begin{array}{l}\text { Municipal Literacy Toolkit by the } \\
\text { Toronto Women's City Alliance } \\
\text { (TWCA) } \\
\text { Non-profit organization } \\
\text { The TWCA created a graphic booklet } \\
\text { that aims to help women and girls } \\
\text { advocate for their rights in Toronto. It } \\
\text { broadly describes "how the City works" } \\
\text { and how readers can get involved. } \\
\text { (Toronto Women's City Alliance, n.d.) }\end{array}$ & $\begin{array}{l}\text { People Plan Toronto (PPT) } \\
\text { Non-profit organization } \\
\text { PPT is a volunteer group with a goal of } \\
\text { ensuring that the public is educated, } \\
\text { engaged, and empowered on the subject } \\
\text { of urban planning issues in Toronto. It } \\
\text { created a planning glossary and } \\
\text { advocated for the creation of a planning } \\
\text { resource centre. } \\
\text { (People Plan Toronto, n.d.-a; People } \\
\text { Plan Toronto, n.d.-b) }\end{array}$ \\
\hline
\end{tabular}

Local media outlets (such as the Toronto Star, Metro News and CBC) have also played important roles in making planning issues and decision-making at City Hall more mainstream and accessible to the public, thanks to dedicated urban affairs reporting.

(v) Why measure planning literacy?

The outcomes of decisions about planning, land use and the built environment are important to people. Residents care about their homes and neighbourhoods, and want to feel like they can influence decisions and plans that will impact the safety, convenience, beauty and charm of where they live (Nabatchi \& Leighninger, 2015, 155). As noted above, public participation has become a common practice because decision makers recognize this desire for influence, and seek to improve decisions by incorporating local knowledge into the calculus (Innes \& Booher, 2004).

Ineffective engagement in land use planning matters can not only negatively impact how people feel about politics, government and the community, but also often leads to cost overruns, construction delays and lost investments (2015). To the extent that knowledge gaps between planners, developers, public officials, special interest groups and citizens are a contributing factor to ineffective engagement, planning literacy (which seeks to close, or at least be aware of these gaps) becomes a relevant topic for planners and for society more broadly. 
Despite a clear motivation to improve the average Torontonian's planning literacy, City Planning does not currently have a targeted understanding of what the average Torontonian knows or should know about planning, nor does it seem to have a plan for benchmarking progress. Though it implies the term “planning literacy” to mean "an understanding of planning concepts, principles and processes” in the above Opportunity for Change, Growing Conversations does not actually define it. Conversations with participants from City Planning confirmed that the division does not have any tools to assess or measure planning literacy. To that end, what specific planning knowledge does City Planning wish to improve among residents in the City of Toronto, and how will it recognize improvements?

This research paper proposes to create a questionnaire that can broadly assess adult (18+) Torontonians' planning literacy levels, based on literacy measurement tools in available literature and input provided from various stakeholders in the city-building field. The legal voting age is proposed as the minimum threshold, because it reflects the age that people in Ontario are assumed to have the capacity to participate in civic decision-making.

Literacy research in other domains suggests why assessing literacy is important. Food literacy literature suggests that it is important to develop shared understandings of what knowledge and skills in that domain should be required, in order to guide efforts and investment at individual, community and population levels (Vidgen \& Gallegos, 2014, 51). Health literacy may have both personal and societal benefits, and has profound implications for approaches to education and communication (Nutbeam, 2000, 264). Increasing consumer financial literacy has been named a public policy objective to improve welfare through better decision-making (Huston, 2010, 296); assessing it is important to provide a baseline and set benchmarks for strategies and programs (OECD INFE, 2011). While City Planning states that expanding efforts to "build Torontonians' understanding of planning concepts, principles and processes will go a long way towards more inclusive engagement, and more relevant, accessible communication” (Toronto City Planning, n.d.-b), it does not propose to assess it. 
By developing a definition for "planning literacy" and a questionnaire for assessing it, this study hopes to stimulate discussion around what all Torontonians should know about planning, and to provide a diagnostic tool that can help advance the planning literacy goals to come out of Growing Conversations.

\section{B. What is planning literacy?}

As "planning literacy” is not a frequently-used term with a commonly-accepted dictionary definition, a literature review was conducted to explore what it might mean.

A review of academic and grey literature produced very limited results on planning literacy as a construct. No clear attempt to define "planning literacy” (or “urban planning literacy”, "land use planning literacy”, “municipal planning literacy” or other closely-related concepts) was found. To inform a working definition, literacy constructs in other domains were examined, and are set out in the following section.

Definitions of literacy in other domains

The term "literacy" is increasingly being used to describe the knowledge and skills needed to navigate a range of other societal systems, such as health, nutrition, science and finance, among others (Vidgen \& Gallegos, 2014, 50; Frisch, Camerini, Diviani, \& Schulz, 2012; Nutbeam, 2008; Doustmohammadian et al., 2017; OECD, n.d.). Modern definitions of literacy in other domains are multidimensional and contextual in nature (Frisch et al., 2012). Examples of literacy definitions in other domains are set out below in Table 2.

Table 2 Definitions of literacy in other domains.

\begin{tabular}{|l|l|}
\hline Domain & Definition of literacy \\
\hline $\begin{array}{l}\text { Functional } \\
\text { (reading/writing) }\end{array}$ & $\begin{array}{l}\text { “[...] the ability to identify, understand, interpret, create, communicate and } \\
\text { compute, using printed and written materials associated with varying context. } \\
\text { Literacy involves a continuum of learning in enabling individuals to achieve their } \\
\text { goals, to develop their knowledge and potential, and to participate fully in their } \\
\text { community and wider society.” (OECD, n.d.) }\end{array}$ \\
\hline
\end{tabular}




\begin{tabular}{|c|c|}
\hline & $\begin{array}{l}\text { "[...] far more than a binary category 'can/cannot read and write'. Instead, it refers } \\
\text { to a wide range of practices people are empowered to participate in, through } \\
\text { having skills in using language in particular ways [...] a collection of skills that } \\
\text { allow for effective participation and influence in diverse areas of social life.” } \\
\text { (Stibbe, 2009, 11) } \\
\text { "Literacy in the broadest sense consists of understanding (i.e., knowledge of } \\
\text { words, symbols and arithmetic operations) and use (ability to read, write and } \\
\text { calculate) of materials related to prose, document and quantitative information.” } \\
\text { (Huston, 2010, 306) }\end{array}$ \\
\hline Financial & $\begin{array}{l}\text { "A combination of awareness, knowledge, skill, attitude and behaviour necessary } \\
\text { to make sound financial decisions and ultimately achieve individual financial } \\
\text { wellbeing.” (OECD INFE, 2011, 3) } \\
\text { “[...] a measure of the degree to which one understands key financial } \\
\text { concepts and possesses the ability and confidence to manage personal finances } \\
\text { through appropriate, short-term decision-making and sound, long-range financial.” } \\
\text { (Remund, 2010, 284) } \\
\text { "Financial literacy could be conceptualized as having two dimensions- } \\
\text { understanding (personal finance knowledge) and use (personal finance } \\
\text { application) [...] following the proposed conceptual framework, financial literacy } \\
\text { could be defined as measuring how well an individual can understand and use } \\
\text { personal finance-related information.” (Huston, 2010, 306) }\end{array}$ \\
\hline Food/nutrition & $\begin{array}{l}\text { "Food literacy is the scaffolding that empowers individuals, households, } \\
\text { communities or nations to protect diet quality through change and strengthen } \\
\text { dietary resilience over time. It is composed of a collection of inter-related } \\
\text { knowledge, skills and behaviours required to plan, manage, select, prepare and eat } \\
\text { food to meet needs and determine intake.” (Vidgen \& Gallegos, 2014, 50; Krause } \\
\text { et al., 2018, 275) } \\
\text { "A collection of inter-related knowledge, skills and behaviors required to plan, } \\
\text { manage, select, prepare and eat foods to meet needs and determine food intake.” } \\
\text { (Doustmohammadian et al., 2017, 2) } \\
\text { "The degree to which individuals can obtain, process, and understand the basic } \\
\text { nutrition information and services they need to make appropriate nutrition } \\
\text { decisions, with the qualification that the definition is nutrition specific.” (Silk et } \\
\text { al., 2008, 4; Guttersrud et al., 2013). } \\
\text { "Nutrition-specific health literacy encompasses the skills and knowledge related to } \\
\text { maintaining balanced, sustainable, and health promoting nutrition” (Krause et al., } \\
\text { 2016, 218) }\end{array}$ \\
\hline Health & $\begin{array}{l}\text { "[...] the ability to perform basic reading and numerical tasks required to function } \\
\text { in the healthcare environment” (Chew et al., 2004, 588) } \\
\text { "[...] the degree to which individuals have the capacity to obtain, process, and } \\
\text { understand basic health information and services needed to make appropriate } \\
\text { health decisions.” (Davis \& Wolf, 2004, 595) }\end{array}$ \\
\hline
\end{tabular}




\begin{tabular}{|c|c|}
\hline & $\begin{array}{l}\text { "[...] the cognitive and social skills which determine the motivation and ability of } \\
\text { individuals to gain access to, understand and use information in ways which } \\
\text { promote and maintain good health. Health Literacy means more than being able to } \\
\text { read pamphlets and successfully make appointments. By improving people's } \\
\text { access to health information and their capacity to use it effectively, health literacy } \\
\text { is critical to empowerment." (World Health Organization, n.d; Nutbeam, 2008, } \\
\text { 2074; Nutbeam, 2015, 451; Osborne et al., 2013, 2). }{ }^{4}\end{array}$ \\
\hline Information & $\begin{array}{l}\text { "[...] the ability to know when information is needed [and] the ability to locate, } \\
\text { evaluate and use information effectively." (Kong, 2007, 60) } \\
\text { "[...] a person's information ability including the skills of managing information } \\
\text { and the knowledge of applying information [...] Information literacy includes: (1) } \\
\text { the knowledge of information [sic] system; (2) the skills for acquiring, analyzing, } \\
\text { organizing, and evaluating information; (3) understanding the value, functions, } \\
\text { and roles of information; (4) utilizing information for solving problems.” (Wen \& } \\
\text { Shih, 2008, 788) }\end{array}$ \\
\hline Sustainability & $\begin{array}{l}\text { "More than knowledge about sustainability [...] the skills, attitudes, competencies, } \\
\text { dispositions and values that are necessary for surviving and thriving in the } \\
\text { declining conditions of the world in ways which slow down that decline as far as } \\
\text { possible." (Stibbe, 2009, 10) } \\
\text { "[...] a bundle of knowledge, attitudes, and skills about sustainability... [that] can } \\
\text { be developed through social learning, i.e., experiences in which participants build } \\
\text { understanding and shape their values through collaboration with others." (Cohen } \\
\text { et al., 2015, 8711) }\end{array}$ \\
\hline Civic & $\begin{array}{l}\text { "[...] the knowledge and capacity of citizens to make sense of their political } \\
\text { world.” (Millner, 2002) } \\
\text { “... civic competence [is] the knowledge, skills, attitudes and values needed to } \\
\text { enable individuals to become an active citizen.” (Hoskins et al., 2008, 11) }\end{array}$ \\
\hline Cultural & $\begin{array}{l}\text { "Cultural literacy includes cultural competence, but adds to it the ability to } \\
\text { critically reflect on, and if necessary bring about change in, one's own culture. It } \\
\text { also includes the ability to analyze the behaviours of dominant cultures in relation } \\
\text { to other cultures." (Polistina, n.d. in Stibbe, 2009, 117) }\end{array}$ \\
\hline Science & $\begin{array}{l}\text { "[...] an understanding of the norms of science[,] knowledge of major scientific } \\
\text { constructs[, and] awareness of the impact of science and technology on society } \\
\text { and the policy choices that must inevitably emerge.” (Miller, 1983, 31) } \\
\text { "[...] the capacity to use scientific knowledge to identify questions and to draw } \\
\text { evidence based conclusions in order to understand and help make decisions about } \\
\text { the natural world and the changes made to it through human activity” (OECD, } \\
2003,133)\end{array}$ \\
\hline
\end{tabular}

\footnotetext{
${ }^{4}$ According to Nutbeam $(2015,451)$, the World Health Organization (n.d) health literacy definition highlights the fact that health literacy represents "an observable set of cognitive and social skills that will vary from individual to individual. It also emphasizes that these skills enable individuals to obtain, understand and use information to make decisions and take actions that will have an impact on their health status." The definition reflects that health literacy is not just a set of functional capabilities, but that it "comprises a set of skills that enable people to participate more fully in society, and to exert a higher degree of control over everyday events” (Nutbeam, 2008, 2075).
} 
There are different ways to break down and understand the themes that emerge from the various definitions. A selection of effective approaches used in the literature are described in the next two subsections.

(ii) Nutbeam's three levels of health literacy

One approach to literacy has been to classify it in different types (functional, interactive and critical), reflecting not measures of achievement in reading and writing, so much as what it enables people to do (Freebody \& Luke, 1990). Nutbeam (2000; 2008; 2015) adapted these classifications to apply in a health literacy context, noting that each one progressively allows for greater autonomy and personal empowerment in decision-making, as well as engagement in health-related actions $(2008,2075)$. They are described as follows:

1. Functional health literacy is described as "basic health literacy skills that are sufficient for individuals to obtain relevant health information (for example on health risks, and on how to use the health system), and to be able to apply that knowledge to a limited range of [...] activities” (Nutbeam, 2015, 451). They are the "basic skills in reading and writing” that enable people to “function effectively in everyday situations” (Nutbeam, 2000, 263; Nutbeam, 2008, 2075).

2. Interactive health literacy describes more advanced cognitive and literacy skills that can be used to actively participate in everyday activities (Nutbeam, 2008, 2075). Specifically, these skills enable individuals to extract information and derive meaning from different forms of communication (e.g. interpersonal, mass media) and to apply new information in changing circumstances. They enable individuals both to act independently on new information, and to interact with greater confidence with information providers (such as health care professionals) (Nutbeam, 2015, 451). 
3. Critical health literacy describes more advanced cognitive skills which, together with social skills, can be applied to critically analyze information, and to use that information to exert greater control over life events and situations (Nutbeam, 2000, 264; Nutbeam, 2008, 2075; Nutbeam, 2015, 451). Measuring critical health literacy is demanding and not always possible, and question wording and social context are important for answering such questions (Krause et al., 2016, 218).

These levels of literacy are meant to reflect relative differences in relevant cognitive and social skills, and differences in individual abilities to apply their skills to achieve certain outcomes in different circumstances (Nutbeam, 2015, 451). They have been used as a guiding framework in health and healthrelated (e.g. food and nutrition) questionnaires (Osborne et al., 2014; Doustmohammadian et al., 2017; Krause et al., 2018). Given the logical and generalizable approach to understanding different levels of literacy, this research paper proposes to adapt them to apply in a planning context.

\section{(iii) Dimensions of literacy}

In their study on defining and measuring health literacy, Frisch et al. (2012) critically reviewed literacy concepts across seven domains (civic, cultural, information, media, new media, political and science/scientific). They found that the definitions were generally made up of the following “dimensions”: (1) functional literacy, (2) factual knowledge, (3) procedural knowledge, (4) awareness, (5) critical dimensions, (6) affective dimension and (7) attitudes. Each dimension is described below.

Functional, or fundamental, literacy is the "ability to identify, understand, interpret, create, communicate, compute and use printed and written materials associated with varying contexts” (UNESCO Education Sector, 2004, 13; Frisch et al., 2012, 121). Functional literacy is important, as it is through reading and writing that people are able to participate more fully in society, both economically 
and socially, and understand and exert a higher degree of control over everyday events (Nutbeam, 2008, 2072). Frisch et al. (2012) referred to it as the "basic dimension of literacy concepts" in all the domains they reviewed.

Factual knowledge enables people to process and understand different types of information (written, oral and visual) in a specific context (Frisch et al., 2012, 121). Procedural knowledge differs from factual knowledge, in that it refers to the "know how" of how to actually use factual knowledge (Frisch et al., 2012, 121). For example, in science literacy, this means having the capacity to use scientific knowledge (OECD, 2003). In information literacy, it is about having the skills for acquiring, analyzing, organizing, and evaluating information (Wen \& Shih, 2008, 788; Frisch et al., 2012, 122). In health literacy, this means having the ability to obtain and use health-related information (Frisch et al., 2012, 122; Davis \& Wolf, 2004).

Awareness is also a central dimension in all the literacy concepts reviewed by Frisch et al. (2012, 122). In political literacy, it reflects "the extent to which an individual pays attention to politics and understands what he or she has encountered” (Frisch et al., 2012, 122; Zaller, 1992). In health literacy, it is being “aware that individual health decisions can affect public health” (Frisch et al., 2012, 122; Zarcadoolas et al., 2006). In science literacy, it is the awareness of "the impact of science and technology on society and the policy choices that must inevitably emerge” (Miller, 1983, 31).

Many literacy definitions include a critical dimension, which relates to the ability to extract meaning from information, apply one’s own judgment and act on it (Frisch et al., 2012). Nutbeam (2000, 2075) notes that health literacy "can be categorized into different levels that progressively reflect greater autonomy and personal empowerment in decision-making, as well as engagement in a wider range of health actions that extend from personal behaviours to social action to address the determinants of health.” Critical health literacy lies within that spectrum, and reflects a person’s ability to critically 
analyze information and use it to exert greater control over life events and situations. In nutrition literacy, Doustmohammadian et al., $(2017,3)$ define it as “the ability to analyze nutrition information critically, increase awareness, and participate in action to address barriers”. This dimension also appears in financial (OECD INFE, 2011; Remund, 2010; Huston, 2010) and information (Kong, 2007; Wen and Shih, 2008) literacy definitions.

Finally, some literacy concepts include an affective dimension and/or references to attitudes (Frisch et al., 2012, 123). Kong $(2007,61)$ proposes that developing information literacy includes "the cultivation of attitudes towards information processing in the affective and socio-cultural domains”. The affective dimension in information literacy addresses "the need for [people] to appreciate and enjoy the process of inquiry”, and the socio-cultural dimension addresses "the need to empower [students] with greater autonomy and social responsibility over the use of information [...]” (Kong, 2007, 61). Attitudes in information literacy also appear in Wen and Shih’s $(2008,789)$ definition.

(iv) Other key takeaways from literacy research in other domains

What constitutes satisfactory literacy performance is historically and culturally determined (Freebody \& Luke, 1990, 7). In an exploration of planning literacy, this a reminder of how important it is to understand local expectations, priorities and objectives around what City Planning and other practitioners in the citybuilding field believe the public should know about planning.

Nutbeam $(2015,451)$ notes that health literacy is content- and context-specific, suggesting that a person's ability to access health information and their motivation to use it will be influenced by their age and stage in life, and the context in which the information might be applied. Because of this variability, developing a universal population measure for health literacy has been difficult. Similar challenges are faced in developing a measure for planning literacy. 
In financial literacy, the level of overall "endowed and attained human capital”, as well as behavioral and cognitive biases, self-control problems, family, peer, economic, community and institutional influences

can impact a person's literacy (Huston, 2010, 307). Parallel conclusions could potentially be drawn in the context of planning literacy. For example, a person with stronger functional literacy is probably more likely to have higher planning literacy skills than someone with weak functional literacy. Additionally, someone who does not have time or interest or does not see the value in developing planning knowledge could be reasonably expected to have lower planning literacy. These are matters for further potential study.

\section{Measuring planning literacy: Looking to precedents}

Unsurprisingly, the literature review also produced very limited results on how to measure planning literacy. No clear attempts to measure planning (or "urban planning literacy”, "land use planning literacy”, “municipal planning literacy” or other closely-related concepts) literacy were found. Given the lack of precedents in planning, literature on literacy assessment and literacy questionnaires in other domains were reviewed to inform the potential structure of a planning literacy questionnaire (PLQ).

The literature suggests that when developing an instrument to measure [financial] literacy, it is important to determine not only if a person knows the information, but also if he/she can apply it appropriately (Huston, 2010, 307). Assessments should "focus on designing items strongly linked to the most common and/or most detrimental [financial] mistakes” (2010, 307), and “attention to item wording and ordering is important regardless of the data collection technique used” (2010, 309). Furthermore, some rating method, such as a threshold or ranking system, is "imperative to ensure common interpretation of the results” (2010, 309). 
Krause et al.’s (2016; 2018) short food literacy questionnaire (SFLQ) was selected as an ideal base precedent for the PLQ for its clarity, length and logical incorporation of Nutbeam's (2008; 2015) three levels of health literacy. The general process followed to create the SFLQ and final item structures from the questionnaire are set out below and in Appendix D. A financial literacy questionnaire is also included for additional reference (OECD INFE, 2011).

\section{(i) Short food literacy questionnaire (SFLQ)}

Krause et al. (2016) developed a short food literacy questionnaire (SFLQ) in the context of an environmental and educational workplace intervention trial. The questionnaire aimed to ensure that the competencies of nutrition-specific health literacy (i.e. the skills and knowledge related to maintaining balanced, sustainable, and health promoting nutrition) could be comprehensively measured so that their influence on eating behavior could be assessed (2016, 218). It draws upon Nutbeam's (2008) functional, interactive, and critical elements of food literacy, in order to build food literacy scores for application in public health practice settings.

The questionnaire was developed in the following stages: (1) acquisition of background materials, (2) questionnaire development, and (3) a two-stage pre-test (Krause et al., 2016, 215). In Stage 1, the authors searched and analyzed existing definitions of nutrition and food literacy and their core elements, in comparison to established concepts of health literacy. The authors produced a grid summarizing the definitions in twelve themes, and classified them as functional, interactive or critical (see Table 4 in Appendix D). The grid led to a working definition which guided the development of their items (Krause et al., 2016). The authors initially found 110 existing validated health, nutrition and/or literacy measurement instruments, which they narrowed down to 24 instruments that they used to inform their SFLQ. 
At Stage 2, the authors selected items from precedent instruments and assigned them to the themes in the grid. They also developed new items for themes that did not have suitable corresponding items from the literature, maintaining a focus on health and balanced nutrition. They phrased items in "comprehensible language, avoiding the use of technical terms” (Krause et al., 2016, 215). At the end of Stage 2, a group of experts in nutrition, health literacy and questionnaire development reviewed the items for face validity, which "checks whether the questions are meaningful and appropriate and whether they fully capture the construct to be tested” (Krause et al., 2016, 215). Questions were updated and reviewed again by the experts. The final stage involved pre-testing the SFLQ on consenting subjects (in cognitive and standard pre-tests) to determine whether the groups understood the questions and the corresponding response formats, as well as further expert evaluations, leading to further changes (Krause et al., 2016, 216). Cognitive pre-tests were the most important element in optimizing the comprehensibility of questions among the target population (Krause et al., 2016, 218).

A follow-up study (Krause et al., 2018) evaluated the measurement properties of the SFLQ, testing its items for internal consistency and construct validity, and ultimately cutting down the questions from 16 to 12. The final 12-question SFLQ is set out at Table 5 in Appendix D. Demographic information asked of participants included age, gender, household structure, education, employment (i.e. whether people engage in mostly manual or sedentary type of work), and self-rated health (see Table 6 in Appendix D).

\section{(ii) $\quad$ Financial literacy questionnaire (FinLQ)}

The OECD International Network on Financial Education (INFE) developed a financial literacy questionnaire (FinLQ) and guiding document on how to administer it (OECD INFE, 2011). It was created to help public authorities and other organizations collect data with the goals of enabling the following: 
1. An initial measure of financial literacy to identify national levels of financial literacy, provide a baseline and set benchmarks for national strategies or particular programmes;

2. A description of levels of financial literacy in terms of key socio-demographic groups and explanatory variables that will enable policymakers to identify the needs of the population, the groups with the greatest needs and the gaps in provision;

3. The opportunity to conduct repeat measures of financial literacy to identify change over time; and

4. A comparison of levels of financial literacy across countries (OECD INFE, 2011, 3).

The FinLQ was developed based on the OECD INFE's (2011, 3) definition of financial literacy, recommendations in an OECD working paper (Kempson, 2009) and internal OECD INFE discussion papers that were not available for review. The items aim to cover a mixture of attitudes and knowledge, and capture behaviour relating to topics such as money management, planning for short- and longer-term financial goals, and awareness and choice of financial products (OECD, 2011, 4), consistent with four dimensions originally proposed by Kempson $(2009,4)$. It also collects demographic information, such as age, gender, family circumstances, work status, income, income stability), educational level and region (OECD INFE, 2011). Kempson’s (2009) dimensions and core items created for each are set out in Table 7 in Appendix D. The final FinLQ is provided in Table 8 in Appendix D.

The FinLQ is intended to cover all adults aged 18 to 79 (OECD INFE, 2011, 6), as in most developed economies, "18 is the age when most individuals begin to adopt some autonomy with regard to their finances and become legally permitted to use the various sources of credit, including current accounts that can be overdrawn” (Kempson, 2009, 11). Collecting the exact age of survey participants, as opposed to collecting it in age bands, was recommended to allow for greater flexibility when analyzing and crosscomparing results $(2009,11)$. 
The FinLQ was selected to provide an additional perspective on approaches to assessing literacy.

However, because it was designed to be administered personally (either over the phone or face-to-face), rather than self-completed online, and as a national survey that can be used in countries worldwide, there may be some limitations as to how much the FinLQ can be relied on as a model for the PLQ (unless the PLQ is also administered offline).

Local policies and initiatives and literature on literacy in other domains suggest that there is value to be gained from measuring planning literacy in Toronto, by using it to improve local processes and empower interested residents to participate in city building conversations. While no literature was found on defining and measuring planning literacy specifically, research from other domains, local policy priorities and insights from people with meaningful experience in public engagement will inform a definition of "planning literacy” and the structure and contents of the PLQ. 


\section{Method}

While no previous studies or questionnaires measuring planning literacy or planning knowledge were found in the literature review, there are many studies that have developed tools to measure other types of literacy. To develop a fulsome definition of planning literacy and the planning literacy questionnaire (PLQ), this research paper is primarily guided by the approach followed by Krause et al. (2016) in creating and validating their SFLQ. The study was selected for its clear and logical approach to breaking down larger concepts into detailed dimensions and items.

This research paper follows the following phases: (1) identify the themes and dimensions of planning literacy to develop a working definition of the term, (2) use the findings from the previous phase to develop the PLQ, and (3) get feedback and revise the PLQ. The final PLQ is set out at Appendix E.

\section{A. Develop a working definition of "planning literacy"}

Planning literacy themes were developed using Nutbeam’s (2000; 2008; 2015) three levels of literacy (functional, interactive and critical) and local challenges and priorities identified through the literature review, participant interviews and City of Toronto policies. The dimensions identified by Frisch et al., 2012 were also considered.

\section{(i) Literature review}

A search of Ryerson University’s library catalogue, Google Scholar, Google and print publications was conducted to identify concepts of literacy in urban planning and other domains, as well as related questionnaires. Searches included terms such as "planning literacy”, “urban planning literacy”, "land use planning literacy”, “literacy”, “municipal planning literacy”, “planning knowledge”, “planning education”, “urban pedagogy” and “planning pedagogy”. Relevant studies and definitions were used to 
develop an initial construct of "planning literacy”, which was then expanded upon using participant interview results and the policy review in Section II.

\section{(ii) $\quad$ Participant interviews}

15 participants (see Appendix A) with a range of experiences in public engagement related to city planning in Toronto and beyond were asked to answer a list of questions on planning literacy. These questions (see Appendix B) asked about their perceptions and knowledge of planning literacy as a construct, what key planning concepts the public should know and/or be tested for, relevant organizations and initiatives dedicating to building planning literacy, and for advice on how to create an effective PLQ. Semi-structured discussions took place in-person or over the phone (up to a maximum length of 60 minutes per interview). Some participants opted to provide written answers via email. Written transcripts (or emailed answers, as applicable) were compiled, reviewed and summarized to identify key themes that could inform the definition of planning literacy and items to include in the PLQ.

Nine participants (\#1, \#3, \#4, \#6, \#8, \#10, \#11, \#12 and \#13) gave answers based on their experiences in roles and/or organizations (non-profit and public sector, including one in City Planning) specifically dedicated to improving community knowledge and engagement in civic and planning matters. Three participants (\#7, \#9 and \#14) had experience as private or public sector planners who regularly engaged with the public as a part of their jobs. Two participants (\#5 and \#8) had experience as community members representing fellow resident concerns in local planning matters. One participant (\#2) spoke with reference to his work as a constituency assistant to a local councilor in one of the City of Toronto's densest and most active wards. Most participants provided answers based on their experiences in the City of Toronto. Participants \#3, \#9 and \#13 gave answers based on their experiences in major cities in the United States and another Canadian province. 
A public meeting was also attended in May 2017, where numerous planning terms and concepts used by the city planner facilitating the meeting were recorded for potential inclusion in the PLQ (see Appendix C).

\section{B. Develop and get feedback on the PLQ}

Using the themes, dimensions and inputs from the previous phase, questionnaire items were developed for an 18+ City of Toronto audience. Krause et al.'s (2016; 2018) SFLQ, OECD INFE’s (2011) FinLQ, a questionnaire used by City Planning in Growing Conversations and other literacy questionnaires were drawn upon.

From there, the questionnaire was circulated to select participants from the previous phase, to assess items for relevance, clarity, ambiguity and complexity (i.e. a "cognitive pre-test”, a key element in ensuring that items are consistently understood in accordance with their intended meaning (Krause et al., 2016, 218)) and to generate further discussion. Their input was used to revise the items and produce the final PLQ attached at Appendix E.

\section{Limitations}

Planning is an extremely broad and multidimensional field that benefits from many different types of knowledge. The PLQ has been designed to be applied in a narrow context, i.e. by city planners in the City of Toronto City Planning division, with the goal that its results be used to inform potential changes to future engagement and education efforts. Since planning priorities (which inform planning literacy objectives and in turn, the definition and assessment) differ depending on the local context, the PLQ should not be used as a universal tool. However, the PLQ includes a large number of questions that an end-user could select from, and that can be adapted to suit local or organization-specific needs. 
As noted above, certain participants (\#3 and \#13) provided input in the context of their experiences in the United States, as they were not familiar with the City of Toronto. This research paper assumed that the planning processes and engagement challenges those participants were familiar with are substantially similar to those in Toronto. To account for any differences in local policies and priorities, this paper primarily relied on those participants' input to identify higher-level themes and general recommendations, and avoided putting items in the PLQ that might have been specific to their local processes.

Due to limited resources, the PLQ was not formally administered, beyond an initial review by participants from Phase A, and does not propose a formal methodology for analyzing, scoring or reporting the results. It is more concerned with identifying specific gaps in knowledge, rather than applying labels to respondents. 


\section{Key findings and insights}

Input from participants familiar with local planning culture, processes and priorities is especially important in the development of a questionnaire to measure planning literacy in Toronto, given Freebody and Luke’s $(1990,7)$ observations on the relevance of history and culture on notions of literacy, how broad the PLQ has the potential to be, and this research paper's objectives to create a questionnaire that aligns with local priorities. Participants provided insightful and widely varying answers on what they understood planning literacy to mean, the relationship between planning literacy and local democratic processes, what they thought residents of the City of Toronto should know about planning, and how to develop an effective questionnaire.

\section{A. Defining "planning literacy"}

Many participants had either never heard the term "planning literacy” before, or had only come across it colloquially. Numerous participants (\#4, \#10, \#11 and \#15) specializing in public engagement and facilitation noted that their lines of work were in large part dedicated to improving planning literacy (and that the term does come up at consultations and in meetings, but that internally they did not really use the term to describe it. The same participants said that in practice, they tend to use the terms "civic literacy" or "urban literacy” instead. Participant \#14, a community planner, said that City Planning often uses the term "building capacity” synonymously with the broad concept of planning literacy, and that it comes up frequently within internal City Planning dialogues as a priority when talking about consultations. Two participants seemed to encounter it often: Participant \#6, an engagement specialist at the City of Toronto, said it was a frequently-used "standard industry concept", though he had never come across a universal definition for the term, and Participant \#2, a constituency assistant to a local councilor, noted that it comes up “daily in the context of Committee of Adjustment and rezoning applications”. 
Participants had different approaches to defining “planning literacy” and what it means to be "planning literate”. Participants \#1, \#3 and \#7 noted challenges in trying to come up with a definition. One participant (\#3) thought the term was "too broad to be an effective label, [given] the idea of planning can cover so many different areas and policies”, like “community planning and urban design, but also sustainability and resilience, transportation, food systems and urban agriculture and good government”. Would a broad definition of literacy mean that one must be literate in all of those fields and more? He asked how one would judge literacy, even if the term "planning literate" were to be dissolved into more fine-grained parts - what boxes would need to be checked in order to become "transportation literate” or “housing literate”? Other participants also noted the breadth of planning, and the fact that planning can take so many different names.

A participant from a non-profit focused on city-building education and community engagement who was familiar with the term (\#12) proposed that planning literacy “typically refers to knowledge and understanding of how a city’s planning processes work. Planning literacy is also about the vocabulary and language of urban issues and about how we communicate about urban issues with a broader public (with 'non-planners')”. She sees planning literacy as part of a process of creating “engaged urban citizens who have a strong sense of a place and a sense of stewardship in their local environment”.

Other participants also raised the theme of understanding processes and players, and the roles of these players (including planners and the public). Participant \#15 viewed planning literacy as, among other things, "understanding of the policies and processes that attempt to govern how the process of planning impacts people’s day-to-day lives" and "the role of different actors that influence the development and implementation of these policies, e.g. 'planners', politicians, stakeholders, citizens”. Another (\#11) saw it as "having a general understanding about what planning entails and what it does not; having a general knowledge of different types of local, regional, and provincial planning processes, policies, and actors (including communities and individuals); understanding which body is responsible for what policies and 
decisions; how these decisions are made and when”. Participant \#10 specifically framed his understanding of planning literacy through the role of the planner, i.e. what planners do (and don't do), and how and why they do it:

"To me, 'planning literacy' is about what the role of the planner is (and how that role can be ambiguous); what planners have an influence over and what they do not; how planners exert their influence - the tools and mechanisms they use to regulate land use; how planners think about cities (and why); and where planners fit in relation to other actors in policy making and decision making (including elected officials, other public agencies, and communities and advocacy organizations.)"

These ideas were consistent with the city planner's comment that the public needs to better understand, in the context of development applications, what is being proposed, and City Planning's role, position and reasoning in the context of such a proposal (\#14).

The ability to understand and talk about built form came up in several participants’ answers. To Participant \#5, planning literacy “is about understanding that built form makes up how you see the community and feel about it... being able to talk about the things that you think are important”, and to Participant \#14, it is about "equipping people with the knowledge they need to ask questions about planning matters, [meaning] buildings themselves, what happens in the buildings, and the spaces between”. Participant \#2 framed it as “an understanding of the interplay between provincial and municipal planning policies, the application process and principles of built form and community benefit”. He suggested that in his day-to-day working for a councilor, he would consider someone who "is aware of growth areas, the City's Official Plan and how a development ought to be relating to and contributing to a neighbourhood” as planning literate. 
Several participants framed planning literacy as a multidimensional concept broadly consisting of some combination of a knowledge element (i.e. knowing what something means, why it is relevant), and an action element (i.e. subsequently knowing how to apply it):

- For Participant \#1, the first part is having "the skill or understanding to make assessments at different scales”. In his view, planning-literate people are empowered to independently and confidently make assessments on various developments in their community. The second part is “being able to take action on it [...] with sensitivity and compassion”, implying an affective element. Another participant (\#15) also implied an affective element, noting that "being planning literate means understanding the lived experience of the individuals and groups that planning decisions impact - this is something that citizens are able to bring to the planning process”.

- To Participant \#14, planning literacy is first about knowing what a planning concept means, and second, why it applies or is important. This was echoed by a member of a residents' association (\#5), who used the example of a median included in a street plan to illustrate his point - why does it need to be there?

- Another participant (\#4) framed planning literacy as understanding and applying concepts: "planning literacy is a practical understanding of the policy, terminology, politics, and civic responsibilities that underlie the planning process. To be 'planning literate' means that one has the ability to understand, interpret, and apply such policy, terminology, politics, and civic responsibilities within one’s role (be it bureaucratic, political, or civilian).”

Finally, others described planning literacy, or aspects of it, as follows: 
- “The general public’s ability to engage in meaningful conversations around planning issues and what they want in their city, aside from one-off municipal elections... the ability to understand how you can get involved in the process” (Participant \#9)

- “A basic understanding of planning concepts and processes” (Participant \#6)

- "The idea that there's some level of knowledge about urban issues that most of a general population of a metropolitan area should have.” (Participant \#13)

- It's "about having the tools to think more creatively" about one's city... "how to play in the sandbox” (Participant \#8)

While it was phrased many ways, overall participant input suggests that planning literacy is not only about having substantive knowledge of certain concepts and processes, but that it is also about knowing where to obtain information, being able to filter out irrelevant information, and having the skills to act on it in a range of circumstances.

\section{B. The relationship between planning literacy and democratic processes}

Given City of Toronto’s emphasis on community participation in public decision-making, participants were also asked to comment on the relationship between planning literacy and democratic processes. While answers varied, they were generally consistent with Participant \#12's suggestion that “broadly speaking, the more planning literate a citizenship is, the more democratic the processes are". While "there are other barriers to participation or impact in local democratic processes [...] establishing a common language and toolkit around planning and urban issues can help foster comfort (the will to participate), understanding (the interest to participate), and results (the ability to ultimately affect outcomes)” (\#12). Participants \#4 and \#10 commented that strong planning literacy enables citizens to enter into local democratic process “armed with knowledge”, and helps create "a shared understanding among planners, elected officials, and community advocates”. Participant \#2 affirmed this, noting that a planning literate constituency is "able to engage with their local representatives in a more productive way", meaning that 
"if they understand the layers of planning policy, they can create a dialogue with the appropriate representative as it relates to their inquiry or issue”.

One participant (\#4) noted that “weak planning literacy does not necessarily weaken local democratic process, but it hinders citizens' abilities to effectively participate if they do not have a basic understanding of the confines within which all parties are working”. For another, clarifying the role of planners and what they can or can’t influence can “help prevent or manage tensions or misunderstandings in processes like community meetings” (\#10). Also raised was the notion that an educated public was a civically-minded public, and that initiatives to educate and connect people help "build ownership over the ideas that shape the places that they live, work and play” (\#3). Two participants (\#9 and \#11) noted that planning literacy gives people the opportunity to influence local decisions outside of the municipal election process.

Participant \#7, a planner in private practice, suggested that to some extent, policy documents that determine how an area should grow are reflective of the people who show up to provide feedback on them, both in terms of demographics and their level of planning literacy. If we want these policy documents to reflect opinions and aspirations of the city’s population, residents need to be provided with the tools needed to be able to properly communicate them. Similarly, another participant (\#3) noted that “knowledge of planning ideas can have a positive impact on public meetings where planning-related decisions are made”. For example, “an individual who understands the importance of elements like ground floor activation or protected bicycle lanes is more likely to support projects that feature those elements when they are raised at [council meetings].”

Many participants (\#3, \#5, \#8, \#10 and \#15) acknowledged a relationship between planning literacy, power and democracy. Participant \#5, who primarily spoke based on his experiences as a concerned resident, was cynical about his relationship with his local councilor and noted that there is a power imbalance that seems to be inconsistent with the goals of planning. He noted that democracy is about 
having input into decisions being made, and being able to see how and why they are made. Another participant (\#3) agreed that “transparency is crucial”. Another noted that while "people are the experts in their own neighbourhoods", planning literacy is "fundamentally about power”, in that one cannot expect a community, with no understanding of the planning process, to have an educated conversation with a developer (\#8). In her view, the questions are how to empower communities and teach them the language of development, so that they can have better conversations with developers - and what is the City of Toronto's role in promoting planning literacy in the city?

Related is the idea that having "an understanding of how the government operates, at every level, is very important to the democratic process.” Participant \#3 said that "when it comes to the policy areas that comprise the broader term of planning, an understanding about why things happen the way they do is important to not only understanding what gets placed on a local ballot but what it means and what it can and can’t do".

A few participants pointed out the relevance of community groups in advocating for local outcomes. In the US context, Participant \#13 noted:

“In [my city], general community members usually take up the challenge of understanding complex planning issues when they join up with community organizations that are advocating for some kind of change around a planning issue. So when the city proposes a rezoning of a neighborhood, the community groups that are affected in that neighborhood will mobilize their community members to advocate for the best possible outcomes for the community. Typically it is during this mobilization process that community members get up to speed on planning issues. In many ways it is the community organizations that are most responsible for understanding what's important in terms of planning literacy, not individual citizens. There is power that arises from 
the community organizing together rather than individual voices providing feedback to the Department of City Planning.”

This was consistent with the comments of Participant \#8, who observed through her community advocacy work that it is better to try to educate people on planning literacy through residents' associations rather than as individuals, as “cynically, people will pay attention when it affects them... until that time, it doesn’t tend to sink in”. Participant \#2 noted that “residents in areas with more development and higher engagement typically have a better grasp of planning [and that] to understand planning levels in a given community, a planner should know the local community associations and other stakeholder groups that exist, and what types of development have occurred in the neighbourhood”. Another participant (\#7), who frequently engages with the public on development applications and other planning matters, noted with some cynicism that "no amount of planning literacy will stop the fight [...] even between planners who have a great deal of literacy will have debates over what things mean”.

A couple of participants (\#2 and \#4) also highlighted the many organizations that stand to benefit from knowledge of local planning literacy levels, including political parties, the Toronto Community Housing Corporation, advocacy groups (such as Association of Community Organizations for Reform Now, Social Planning, Public Interest, Friends of the Greenbelt, Toronto Centre for Active Transportation, Walk Toronto, etc.), the Ontario Professional Planners Institute, municipalities and planning tribunals.

Overall, it is clear that each participant saw a positive relationship between people's planning literacy levels and their ability to actively and meaningfully partake in local democratic processes. Increased planning literacy empowers individuals and communities to represent themselves in city building conversations that are important to them. 


\section{What Torontonians should know about planning}

To provide direction for the PLQ, participants were asked what kind of planning knowledge every citizen of Toronto (or, of a municipality generally, where participants were not familiar with Toronto) should ideally be equipped with. While there were some variations between answers, participants generally did not expect, or think it appropriate to expect, ordinary citizens to have significant levels of planning literacy, as far as knowledge of terminology, best practices, processes and policies.

One participant (\#9) reflected that "people have an expectation that growth and infrastructure planning just kind of happens” - this insight was implicit in a common theme to come out of numerous participants' answers, which was that people should understand how the city is planned and expected to change, both broadly and on a neighbourhood level. Consistent with City Planning priorities set out in the 2013-2018 City Planning Strategic Plan, Participant \#6 said that people should know what the Official Plan is (and that it exists!) and its basic objectives. Other participants with engagement experience in Toronto (\#2, \#6, \#8 and \#9) also specifically suggested that citizens should have a basic understanding of the Official Plan, its objectives, and how it affects their neighbourhoods (e.g. understanding which areas are targeted for faster-paced intensification versus for low, stable growth).

Some participants aspired for more in-depth policy knowledge from the public. Two participants (\#4 and \#7) thought that people should also know what the provincial Growth Plan for the Greater Golden Horseshoe is, so as to understand how the province intends the City of Toronto to grow. One of these additionally thought that the public should also have a basic understanding of the Planning Act and the Places to Grow Act, and how along with the Growth Plan, these acts and policies influence the Official Plan. She also proposed that citizens should have an understanding of the purpose and value of secondary plans, and know the difference between guiding documents and legislation (\#4). A US participant (\#3) similarly thought that people in his city should know the background of and information within the local 
equivalent of the Official Plan, as well as "how the [city] has changed over time, its major economic drivers, displacement patterns, commute and traffic maps, and more.”

A common theme that emerged was that people should broadly understand local planning and civic decision-making processes and the roles and powers of various players within them, including the role of the public and opportunities to effect change (Participants \#1, \#5, \#8, \#9 and \#15). These insights reflect an overlap between planning and civic literacy. A US participant specializing in public civic education (\#3) highlighted that “an understanding of the relationship and dynamics between cities, counties, regional agencies and the state is incredibly important.” One participant (\#4) said that people should know the difference between consultation and engagement, with engagement being designed to achieve “possible increased awareness, participation, support” and consultation to receive "input into public processes”. Participant \#5 gave a practical example of an older lady who cannot cross the road in time before the walk signal expires - who does she call? How does she frame that problem? To him, planning literacy means knowing who to call and how to frame a planning issue properly. Participant \#2 provided similar feedback. Similarly, another participant (\#15) suggested that citizens should know "the formal and informal mechanisms for [them] to learn about the planning process and advocate for outcomes that are important to them”.

Two participants (\#4 and \#9) also noted the importance of understanding how the municipal budget works and how the City pays for infrastructure and major planning projects. Understanding the "roles, responsibilities and potential value” of councilors was also cited as important, in that "citizens should be aware and empowered to contact their political representatives about issues that matter to them, and know that their local representatives and their offices rely on information from the public” (\#4).

A couple participants (\#5 and \#9) suggested that people should also know where decision-making information comes from and how it can be accessed (e.g. on the Toronto Meeting Management 
Information System (TMMIS)), how to depute on matters important to them, and how to get informed about development proposals and planning initiatives in their neighbourhoods. In terms of specific processes, Participant \#6 said that people should know the development application process at a high level (i.e. how an application gets approved or rejected) and their roles within it (i.e. where in the process someone can make a meaningful impact, and what elements of a projects someone can change). Another participant (\#1) thought that people should know what development application signs mean.

Multiple participants specifically emphasized that the public should ideally understand more about the role of planners: what planners (and in particular, city planners) do, and what they do not and cannot do. Participant \#10 suggested that public should know that "planners do not build [so much as] create policies that regulate how others build”, the scope of planners' influence on matters such as land use, built form and specific occupants, the role of planners as advisors rather than decision makers, and that "planners are responsible for thinking of all the various components of the City as a whole [...] even though they are not directly responsible for the development, maintenance, or operation of those assets or services”. Another participant (\#1) similarly noted that many people do not - and should - know what planners are, what they do, and how they are different from architects and engineers.

Two participants (\#4 and \#14) suggested that the public should be able to think more critically about height and density (i.e. built form issues). Participant \#14, speaking from his experience as a community planner, highlighted that while people frequently cite height as their first concern with a development proposal, the actual issue usually ends up being something more nuanced, such as including enough space between buildings or animating the street. His view was that people should ultimately focus on understanding what is important to them in public spaces, and that planners should be able to translate the rest. Participant \#4 suggested that that “citizens should have an understanding that density can be achieved in various configurations within a site, as well as the likely (and unlikely) impacts of density on a given site in a busy city". 
Finally, some participants did not believe that citizens should have any significant planning knowledge, either at all, or in certain areas. Participant \#13, who specializes in urban education and community engagement, hesitated to suggest that there is a base level of planning knowledge that everyone should have, referring to the fact that "participation is a limited resource". Given this, he suggested that "people are busy with all kinds of issues in their lives [...] it isn't clear to me that they should be expected to know anything about planning unless those issues are directly impacting them.” Numerous participants (\#5, \#6 and \#7) highlighted concepts that the public should not be expected to know, such as the content of zoning by-laws, differences between different types of development applications (e.g. a plan of subdivision vs. an official plan amendment vs. a rezoning, etc.) and a range of planning terminology (like “angular plane”, “at grade” and “FSI” - see Appendix C for additional terms). Participant \#6 noted the need to avoid jargon especially in light of deficiencies in basic literacy that he has observed. Conversely, Participant \#2 specifically noted that people should know what “as of right” means, as well as the committee of adjustment and rezoning application processes.

Collectively, participants’ feedback generally suggests that Torontonians should have a high-level awareness of key local planning policies and their intentions, know how to access information related to planning matters of interest to them, understand how decisions are made and the roles of actors within them, and where they fit, as citizens, within planning processes. However, planning jargon and in-depth substantive and procedural knowledge is generally best left to the experts.

\section{Other insights relevant to designing the PLQ}

Finally, participants were asked to provide information on planning literacy measures that they had used themselves or come across (if any), suggest what other information would be important to ask of respondents in a planning literacy questionnaire, and provide any other feedback or advice on how to make the PLQ as useful as possible to city planners. 
None of the participants were familiar with any tools specifically designed to measure planning literacy, including participants from City Planning. However, Participant \#2 said that he measures planning literacy of groups and individuals, "if only to guide our office's approach to discussing a specific project, [because] understanding your audience's level of knowledge of the information being presented to them is important when communicating a project”. One participant (\#3) had seen “one-off questionnaires, but nothing that is permanent or consistently used", and noted that in his work in civic education and public engagement in the US, they had not "definitively" measured planning literacy, but had "run programs that, from the outset, seek to understand everyone's general level of literacy on the topic at hand and then attempt to bring everyone up to the same level [...] Doing so only improves the conversation and ensures that the larger group can be fully engaged, rather than a small, informed subset”. Other participants (\#4, $\# 12$ and \#13) also ask questions before and after their engagement and education initiatives to gauge whether or not people were learning.

Some participants noted the value in finding ways to measure planning literacy. Participant \#15 suggested that "results could be used to identify key areas where literacy needs strengthening as well as processes/methods used to improve planning literacy. It's not just about sharing information but also how to do so in a way that is accessible.” Participant \#2 similarly said that "planners could use the results to determine the level of consultation required on a given development, on where to make further efforts to engage in public education outreach, and also to reach out to communities proactively to refine planning policy”.

Given the potential breadth of the concept of planning literacy, Participant \#3 suggested that the tool be “flexible and customizable, both for the topics at hand (a set of questions for transportation vs. another for urban design, etc.) and also for the audience that it’s targeting”. Furthermore, questions should reflect the local context: “There are certain questions that might be appropriate in Toronto that wouldn't be 
appropriate in San Francisco. Likewise, something appropriate in a larger city might be out of place in a smaller town” (\#3).

According to Participant \#6, there are no specific questionnaire formats used by the City of Toronto. In terms of respondent information to include in the questionnaire, he cited respondent location, age, gender, language spoken at home, ethnicity, annual household income and education as important to include (\#6). An online survey administered in connection with Growing Conversations was shared for use as a precedent.

While less relevant to the design and more to the administration of the questionnaire, multiple participants (\#3, \#12 and \#13) noted the value of obtaining information about people's knowledge or interest in planning over time to track progress. Participants who had experience running interactive education workshops programs on urban topics surveyed people before and after their experiences, to gauge changes in their knowledge or interest on the topics, and found these exercises to be very illuminating. City Planning could consider administering the PLQ on multiple occasions, to gauge changes in planning literacy over time. 


\section{Applying the findings}

\section{A. A proposed definition for planning literacy in Toronto}

Using input from participant interviews and priorities identified in planning policy, Table 3 sets out proposed definitions of function, interactive and critical planning literacy, and identifies broad themes that inform the items in the PLQ. The term "planning initiative” broadly encompasses the four contexts in which City Planning engages with the public, meaning (1) when it receives a development application, (2) when a neighbourhood-based planning process is initiated, (3) when a broader city-wide planning process or special study is initiated, and (4) when it wants to talk about city building (Toronto City Planning, n.d.a, 3).

Table 3 Proposed forms of planning literacy and corresponding planning literacy themes

\begin{tabular}{|c|c|c|}
\hline Form of planning literacy & \multicolumn{2}{|r|}{ Planning literacy themes } \\
\hline \multirow{5}{*}{$\begin{array}{l}\text { Functional } \\
\text { Basic planning literacy skills that are } \\
\text { sufficient for individuals to obtain } \\
\text { relevant planning information, know } \\
\text { what the information means, and } \\
\text { understand where and how the } \\
\text { information applies. }\end{array}$} & I. & $\begin{array}{l}\text { Ability to understand what a planning initiative is } \\
\text { and what it seeks from citizens. }\end{array}$ \\
\hline & II. & $\begin{array}{l}\text { Ability to understand information about planning } \\
\text { initiatives (e.g. terminology commonly used in } \\
\text { public consultations; development application } \\
\text { signs; notices from City Planning, etc.) }\end{array}$ \\
\hline & III. & $\begin{array}{l}\text { Ability to find information about City Planning } \\
\text { initiatives and basic planning policy }\end{array}$ \\
\hline & IV. & $\begin{array}{l}\text { "Having knowledge" of: } \\
\text { a. Different players in the municipal decision- } \\
\text { making process as it relates to planning } \\
\text { initiatives, and their roles (incl. what } \\
\text { planners do and don't do) } \\
\text { b. The development application process } \\
\text { c. Opportunities to engage } \\
\text { d. New planning initiatives as they come up }\end{array}$ \\
\hline & V. & $\begin{array}{l}\text { Ability to determine what planning policies apply to } \\
\text { one's own neighbourhood }\end{array}$ \\
\hline Interactive & VI. & $\begin{array}{l}\text { Ability to understand why City Planning makes } \\
\text { certain recommendations }\end{array}$ \\
\hline $\begin{array}{l}\text { More advanced cognitive and } \\
\text { literacy skills that can be used to }\end{array}$ & VII. & $\begin{array}{l}\text { Ability to apply information about a planning } \\
\text { initiative to one's own situation }\end{array}$ \\
\hline $\begin{array}{l}\text { actively participate in common } \\
\text { planning-related activities. These } \\
\text { skills enable individuals to extract }\end{array}$ & VIII. & $\begin{array}{l}\text { Ability to talk about a planning initiative with city } \\
\text { planners, developers, councilors or other planning } \\
\text { consultants }\end{array}$ \\
\hline $\begin{array}{l}\text { information and derive meaning from } \\
\text { different forms of communication }\end{array}$ & IX. & $\begin{array}{l}\text { Ability to talk about a planning initiative with } \\
\text { friends, family or colleagues }\end{array}$ \\
\hline
\end{tabular}




\begin{tabular}{|c|cl|}
\hline $\begin{array}{c}\text { (e.g. interpersonal, mass media) and } \\
\text { to apply new information in } \\
\text { changing circumstances. They enable } \\
\text { individuals both to act independently } \\
\text { on new information, and to interact } \\
\text { with greater confidence with } \\
\text { information providers (e.g. City } \\
\text { Planners). }\end{array}$ & $\mathbf{X}$. & $\begin{array}{l}\text { Ability to bring a planning-related concern to the } \\
\text { appropriate contact }\end{array}$ \\
\hline Critical & & \\
\hline $\begin{array}{c}\text { More advanced cognitive skills } \\
\text { which, together with social skills, } \\
\text { can be applied to critically analyze } \\
\text { information, and to use that } \\
\text { information to exert greater control } \\
\text { over life events and situations as they } \\
\text { relate to planning initiatives (subject } \\
\text { to limitations on power). }\end{array}$ & XIII. & $\begin{array}{l}\text { Ability to assess information on planning initiatives } \\
\text { from different sources (e.g. media, developers, City } \\
\text { Planning) }\end{array}$ \\
\cline { 2 - 3 } & & $\begin{array}{l}\text { Ability to assess how a planning initiative might } \\
\text { impact a neighbourhood or one's own situation }\end{array}$ \\
\hline
\end{tabular}

Based on the above themes, participant feedback and definitions of literacy in other domains, the following definition of planning literacy is proposed:

“Planning literacy" refers to a set of interrelated cognitive and social skills that reflect one's ability to identify, obtain, understand, critically analyze, evaluate, use and act upon information and knowledge relating to urban planning concepts, processes and initiatives, as well as one's awareness of planning initiatives and an understanding of one's own roles and degrees of influence in decisionmaking processes related to planning initiatives.

This definition incorporates most of the dimensions identified by Frisch et al. (2012), including functional literacy, factual and procedural knowledge, awareness and critical dimensions. Although there is definitely an affective dimension to planning, as noted by Participants \#1 and \#14, this definition avoids affective terms that come up in other definitions of literacy, like “confidence” (Remund, 2010), “attitude” (Stibbe, 2009; Cohen et al., 2015), “behaviour” (Vidgen \& Gallegos, 2014; Krause et al., 2018; Doustmohammadian et al., 2017), and “values” (Stibbe, 2009; Cohen et al., 2015) because they are not relevant to this study's overall question of what Torontonians know, and should know, about planning. 
Planning literacy overlaps and is strengthened by other types of literacy, such as (but not limited to) civic literacy, cultural literacy, sustainability literacy, information literacy and even science literacy - this is a testament to the breadth of planning as a practice. The above definition is intended to be broad and adaptable for different contexts. Various components of it, such as "urban planning concepts, processes and initiatives”, “decision-making processes” and "planning initiatives”, are intended to influenced by local priorities.

\section{B. The Planning Literacy Questionnaire (PLQ)}

The final planning literacy questionnaire (PLQ) is attached at Appendix E. The PLQ has been designed to apply in a City of Toronto context, and attempts to collect information that can give city planners an understanding of people’s function, interactive and critical planning literacy levels relative to City Planning's public engagement priorities. It also includes sociodemographic questions to serve as potential explanatory variables. For example, do specific sociodemographic groups tend to have lower planning literacy? Do particular neighbourhoods appear to be more or less planning literate than others?

The PLQ in its current form is extensive, with 45 planning literacy items and 9 respondent characteristic items. Items have been created to address the majority of the planning literacy themes identified in Section V(A). To reduce risk of survey fatigue (National Research Center, 2016), it can be further shortened and tailored to reflect specific divisional priorities.

The PLQ does not propose a universal participant scoring or rating system. Rather, it primarily seeks to stimulate meaningful discussion within City Planning and the broader planning community around what concepts citizens of Toronto should be reasonably familiar with, identify the concepts for which that is not the case, and consider how to best act on that information. These discussions are particularly timely in light of the current City Planning Strategic Plan’s expiry in 2018; the PLQ could play a strategic role in 
developing a targeted program for expanding upon the planning literacy objectives in Growing Conversations.

The purpose of the PLQ is to help bridge gaps, not to increase divides. However, it is worth considering the potential implications of administering the PLQ. How might respondents feel after taking the PLQ, especially in cases where they have trouble working through the items? Especially if it were to attempt to score or classify respondents as planning "literate”, "illiterate” or along some scale of literacy, is there a risk of reinforcing planning as an elitist "experts-only” field, or of inadvertently discouraging people to participate in future planning processes? The PLQ attempts to clearly communicate (i) acknowledgement by City Planning that it is ultimately its role to ensure all levels of literacy are accounted for in its public engagement and education work, (ii) appreciation for respondents' contributions to helping City Planning improve its approaches (especially considering that participation is “a limited resource”, as noted by Participant \#13), and (iii) a meaningful indication of how PLQ results will be used.

\section{For future reference: Administering the PLQ}

An online survey is proposed as the best main method for learning about the general Toronto adult population's planning literacy levels. Online surveys permit a broad range of question types (and visual aids, if needed), as well as a moderate length (Neuman \& Robson, 2015). They yield moderate response rates (which can result in a meaningful sample size if the survey is shared with a large enough population) and are fastest and cheapest to administer, as compared to paper questionnaires or telephone/in-person interviews (Neuman \& Robson, 2015). Invitations to participate in an online survey can be shared in person and online through various channels (such as email, social media, and through a dedicated website if one exists). City Planning regularly uses digital engagement to collect data; an online survey issued in 2016 for the TOcore planning study solicited over 1,400 responses (Toronto City Planning, 2016, 8). 
There are disadvantages to online surveys. Respondents could give replies that are deliberately wrong, and interviewers cannot probe replies (Kempson, 2009, 14; Neuman \& Robson, 2015). People with literacy problems or who are not literate in English will be excluded from the survey, and it would be challenging to determine how many people are affected in this way (Kempson, 2009, 14). As well, there could be some people with literacy difficulties who will attempt to complete an online PLQ and misunderstand the questions (Kempson, 2009, 14). Online questionnaires can also be problematic for people with impaired sight (Kempson, 2009, 14).

Digital inequality is another major issue to account for. In a study on digital inequality in the City of Toronto, Liu (2017) emphasized the importance of planners recognizing that digital engagement and governance initiatives can be impacted by disparate access to the internet, as well as a lack of digital literacy. These limitations are related to a range of factors that include, among others, income, education and age (Liu, 2017; Haight et al., 2014). An examination of trends in Torontonians' digital activities revealed that individuals with low education levels and the elderly were the most consistently digitally excluded (Liu, 2017, 52). Ethnicity and immigration status also appear to have some effect on internet and computer access. Canadian-born residents or earlier immigrants were found to be $68 \%$ more likely to have internet access than recent immigrants (Haight et al., 2014). Liu (2017, 6) cites numerous studies of internet access by ethnic minorities that have typically found lower levels of access compared to majority groups, often persisting after controlling for socioeconomic variables. In a multiculturally diverse city with a high proportion of immigrants and an aging population like Toronto's, these are relevant considerations to keep in mind.

To reach a wider audience, the PLQ would ideally be administered not only online, but also in paper format, at public consultations or in more neutral public spaces like libraries or community centres, as resources permit, to account for digital inequality and the fact that some people may simply prefer those formats. Survey length also need to be considered; a study of over 100,000 surveys showed that the 
longer a survey is, the less time respondents spend answering each question (Chudoba, n.d.). People can get survey fatigue, which happens when they become overwhelmed with questions or the number of surveys they are asked to take, and can result in lower response rates or incomplete information (National Research Center, 2016). As noted earlier, the PLQ can be shortened as required to account for this.

As the PLQ is intended to be used by City Planning, any best practices followed by City Planning and/or the City of Toronto should be followed in designing and administering it. The Growing Conversations online survey referenced earlier served as one precedent.

\section{After the PLQ: What next?}

(i) Responding to low planning literacy levels

The general consensus among participants was that people with higher degrees of planning literacy are more empowered to participate in and influence local city building discussions and decision-making processes outside of municipal election cycles. Planning literacy skills arm people with knowledge and enable them to take actions that could have an impact on their quality of life in their neighbourhoods and cities. So what happens if the PLQ is administered by City Planning, and results suggest low levels of planning literacy?

In the context of health literacy, Nutbeam $(2015,451)$ suggests two ways to act upon low health literacy results. One course of action is to develop and improve it through organized health and patient education. Another is to "modify the environment" in ways that make it easier for a person with low health literacy to obtain, understand and use information in ways that promote and maintain health. The measurement of health literacy is as much about "identifying ways for services to accommodate people with different health literacy needs as it is about identifying ways of improving an individual's health literacy” (Osborne et al., 2013, 2). 
Similar courses of action exist in the context of planning literacy. City planners do not have the final say on planning decisions, but they hold a special form of power and responsibility in their roles as advisors and shapers of city-building policies that are supposed to be reflective of local communities. To ensure that their engagement efforts are truly meaningful, planners would benefit from identifying areas of weakness in planning literacy, and taking proactive measures to address gaps in knowledge, be it by educating the public or by "modifying the environment", i.e. making relevant information more accessible (both procedurally, by making relevant information easier to find, and substantively, by making it easier to understand).

\section{(ii) The planning literacy continuum}

The choice to educate the public versus to modify the environment depends on resources (e.g. time and money) available to City Planning, the degree of planning literacy that City Planning would ultimately like the public to achieve, and the capacity of stakeholders to absorb planning information. Education costs more than simply reframing information to make it more digestible (and can be challenging to keep up with in light of a constantly evolving policy landscape), but the latter may not always be enough.

It is important to note that planning literacy is a collection of skills that exist on a continuum, as implied by the proposed functional, interactive and critical levels set out in Section V(a), with each level assuming progressively higher degrees of knowledge of planning information and ability to act upon that information. Can City Planning reasonably aspire for individuals to have interactive or critical planning literacy (which are challenging to measure), or is it more feasible to aim for some degree of individual functional planning literacy? Should residents have any planning literacy at all, as suggested by Participant \#13? The division must decide what it would like everyday residents to know, keeping in mind what is reasonable to expect in light of barriers to planning literacy. 
It may be easier to achieve higher levels of planning literacy (functional or otherwise) with residents' associations and community groups, who, as noted by Participants \#8 and \#13, are more likely to be receptive to education efforts than individuals, who tend to only pay attention where planning matters directly affect them, and likely will have less capacity and interest on their own to absorb planning information (whereas organizations that exist to represent community interests will have more capacity and incentive to learn, retain, apply and share knowledge). It may also be more efficient to focus education efforts on local organizations, who are not only well-placed to share their planning literacy knowledge and skills with their communities at appropriate times, but can also use them on behalf of those communities, thus potentially relieving people of the need to have high planning literacy.

(iii) Methods for improving planning literacy

It is important to acknowledge significant efforts already being made to increase public planning literacy in Toronto, with City Planning initiatives like Planners in Public Space and the Street Films video series, and cheerful, informative pamphlets that describe planning processes like Committee of Adjustment applications (Table 1). At the provincial level, the Ministry of Municipal Affairs has committed to creating the "Local Planning Appeal Support Centre”, a new agency that will provide free information and support in planning matters, potentially including representation at the Local Planning Appeal Tribunal for citizens of Toronto (and beyond) who want to participate in appeal processes (Ministry of Municipal Affairs, 2017).

Notwithstanding these efforts, City Planning could increase the breadth of its formal educational initiatives by looking to the City of Ottawa's "Planning Primer” program, a series of half-day courses designed to reach citizens about planning (City of Ottawa, 2017), or by supporting initiatives that can 
provide communities with planning assistance when needed, such as The Planning Clinic or the proposed Planning Resource Centre (Table 1) (People Plan Toronto, n.d.-a).

City Planning should also continue efforts to make relevant information more intuitive to find, and for City Planning materials to be presented in a way that is accessible to people across a wide range of planning literacy levels. A participant with experience in planning and civic literacy-building (\#10) suggests “sharing information in a way that doesn’t talk down or condescend to lay audiences but also avoids excessive technical, legislative jargon” and “using experiential, immersive tools (like neighbourhood walks) to show people tangible, on-the-ground results of planning decisions” to build planning literacy. As well, to improve planning literacy, a planner "must be willing to work closely with a community, to create relationships and a level of trust with local community leaders. Communities will engage if they feel involved and that their feedback is having an impact” (Participant \#2).

\section{(iv) Opportunities for future research}

Recognizing that city planners and everyday citizens are often on different wavelengths and working to identify and reconcile gaps in planning knowledge is an important step to empowering citizens and democratizing planning processes. There are opportunities for future research, especially once the PLQ is administered.

Future research should explore why knowledge gaps exist, and how they can be best addressed. For example, it might identify barriers to planning literacy (such as time, behavioral and cognitive biases, confidence issues, functional literacy deficiencies, and family, peer, economic, cultural, community and institutional influences) and how to address them. Future studies might also expand on how and when residents' planning literacy levels may be most effectively improved, and by whom. For example, perhaps focusing on youth or resident associations’ planning literacy levels will lead to more effective 
engagement outcomes, rather than trying to target individual adult residents. Alternatively, perhaps creating easy-to-access resources that can be used by residents on an as-needed basis (such as the proposed Planning Resource Centre) might lead to more effective and efficient outcomes than top-down approaches that involve formal education efforts. Future research could also explore opportunities to simplify Ontario’s complex planning system, and consider what “effective” engagement outcomes actually look like. Finally, as City Planning implements education programs and/or modifies the engagement environment, the PLQ could be re-administered in the future to re-evaluate planning literacy levels and progress made.

As noted earlier, improving public engagement processes is a perpetual and multifaceted undertaking, within which planning literacy is just one, albeit important, element. Overall, regardless of what PLQ results may reveal and whatever remedies City Planning may decide to pursue, individual city planners should keep in mind the phrase “a fish doesn't know it’s in water”. As members of a profession that calls on its members to "practice in a manner that respects the diversity, needs, values and aspirations of the public and encourages discussion on these matters” (Ontario Professional Planners Institute, n.d.-b), city planners must be mindful of the fact that they may occasionally operate in a "planning bubble” (Biggs, 2016). Once they better understand areas of weakness, city planners should approach their interactions with local communities with sensitivity to potential differences in planning literacy, and respect for why those differences may exist - so that they may continue to effectively "grow the conversation". 


\section{References}

Armour, A. M. (1991). The siting of locally unwanted land uses: Towards a cooperative approach. Progress in Planning, 35, 1-74. https://doi.org/10.1016/0305-9006(91)90007-O

Arnstein, S. (1969). A ladder of citizen participation in the USA. Journal of the American Institute of Planners, 35(4), 216-224.

Bedford, T., Clark, J., \& Harrison, C. (2002). Limits to New Public Participation Practices in Local Land Use Planning. The Town Planning Review, 73(3), 311-331.

Biggs, D. (2016, July 5). The 3 Most Common Community Engagement Mistakes. Retrieved September 20, 2017, from https://www.planetizen.com/node/87219/3-most-common-community-engagement-mistakes

Cartwright, T. J. (1973). Problems, Solutions and Strategies: A Contribution to the Theory and Practice of Planning. Journal of the American Institute of Planners, 39(3), 179-187. https://doi.org/10.1080/01944367308977852

Chew, L., Bradley, K., \& Boyko, E. (2004). Brief Questions to Identify Patients With Inadequate Health Literacy. Family Medicine, 36(8), 588-594.

Chudoba, B. (n.d.). How much time are respondents willing to spend on your survey? Retrieved March 12, 2018, from https://www.surveymonkey.com/curiosity/survey_completion_times/

City of Ottawa. (2017, November 23). Planning Primer. Retrieved March 11, 2018, from https://ottawa.ca/en/city-hall/planning-and-development/community-involvement/planning-primer

City of Toronto. (2013). 2013-2018 City of Toronto Strategic Actions. Retrieved from https://www.toronto.ca/wp-content/uploads/2017/08/8f97-strategic-actions-2013-2018.pdf

City of Toronto. (2017a, August 23). Notice of Proposed Development Application and Public Meeting Sign. Retrieved March 11, 2018, from https://www.toronto.ca/city-government/planningdevelopment/application-forms-fees/notice-of-proposed-development-application-and-public-meetingsign/ 
City of Toronto. (2017b, November 22). Planners in Public Spaces. Retrieved March 19, 2018, from https://www.toronto.ca/city-government/planning-development/outreach-engagement/planners-in-publicspaces/

Cohen, M., Wiek, A., Kay, B., \& Harlow, J. (2015). Aligning Public Participation to Stakeholders’ Sustainability Literacy. Sustainability, 7, 8709-8728. https://doi.org/10.3390/su7078709

Davidoff, P. (1965). Advocacy and Pluralism in Planning. Journal of the American Institute of Planners, 31(4), 48-63. https://doi.org/10.1016/B978-0-08-017066-4.50024-2

Davis, T., \& Wolf, M. (2004). Health Literacy: Implications for Family Medicine. Family Medicine, 36(8), 595-598.

Doustmohammadian, A., Omidvar, N., Keshavarz-Mohammadi, N., Abdollahi, M., Amini, M., \& Eini-Zinab, H. (2017). Developing and validating a scale to measure Food and Nutrition Literacy (FNLIT) in elementary school children in Iran. PLos ONE, 12(6). https://doi.org/10.1371/ journal.pone.0179196

Etzioni, A. (1967). Mixed-Scanning: A “Third” Approach to Decision-Making. Public Administration Review, 27(5), 385-392. https://doi.org/10.2307/973394

Forester, J. (1989). Planning in the face of power. Berkeley: University of California Press.

Freebody, P., \& Luke, A. (1990). Literacies programs: Debates and demands in cultural context. Prospect: An Australian Journal of TESOL, 5(3), 7-16.

Frisch, A.-L., Camerini, L., Diviani, N., \& Schulz, P. J. (2012). Defining and measuring health literacy: how can we profit from other literacy domains? Health Promotion International, 27(1), 117-126.

Gladki Planning Associates, Hemson Consulting, \& Studio Jay Wall. (2017). City of Toronto Official Plan Indicators.

Guttersrud, Ø., Østerholt Dalane, J., \& Pettersen, S. (2013). Improving measurement in nutrition literacy research using Rasch modelling: examining construct validity of stage-specific “critical nutrition literacy” scales. Public Health Nutrition, 17(4), 877-883. https://doi.org/10.1017/S1368980013000530 
Haight, M., Quan-Haase, A., \& Corbett, B. A. (2014). Revisiting the digital divide in Canada: the impact of demographic factors on access to the internet, level of online activity, and social networking site usage. Information, Communication \& Society, 17(4), 503-519.

Healey, P. (1992). Planning through Debate: The Communicative Turn in Planning Theory. The Town Planning Review, 63(2), 143-162.

Hoskins, B., Villalba, E., Van Njlen, D., \& Barber, C. (2008). Measuring Civic Competence in Europe: A composite Indicator based on IEA Civic Education Study 1999 for 14 years old in School (JRC Scientific and Technical Reports). Italy: Institute for the Protection and Security of the Citizen. Retrieved from https://core.ac.uk/download/pdf/38618456.pdf

Huston, S. (2010). Measuring Financial Literacy. The Journal of Consumer Affairs, 44(2), 296-316.

Innes, J. E., \& Booher, D. E. (2004). Reframing public participation: Strategies for the 21st century. Planning Theory \& Practice, 5(4), 419-436. https://doi.org/10.1080/1464935042000293170

JanesWalk. (n.d.). About Jane’s Walk. Retrieved March 19, 2018, from https://janeswalk.org/about/

Kempson, E. (2009). Framework for the Development of Financial Literacy Baseline Surveys: A First International Comparative Analysis. OECD Working Papers on Finance, Insurance and Private Pensions, No. 1. http://dx.doi.org/10.1787/5kmddpz7m9zq-en

Kong, S. C. (2007). The development and validation of an information literacy model for Hong Kong students: key issues in the professional development of teachers for capacity building. Technology, Pedagogy and Education, 16(1), 57-75.

Krause, C. G., Beer-Borst, S., Sommerhalder, K., Hayoz, S., \& Abel, T. (2016). Nutrition-specific health literacy: development and testing of a multi-dimensional questionnaire. Ernahrungs Umschau, 63(11), 214-220. https://doi.org/10.4455/eu.2016.046

Krause, C. G., Beer-Borst, S., Sommerhalder, K., Hayoz, S., \& Abel, T. (2018). A short food literacy questionnaire (SFLQ) for adults: Findings from a Swiss validation study. Appetite, 120(1), 275-280. https://doi.org/10.1016/j.appet.2017.08.039 
Krause, C., Sommerhalder, K., Beer-Borst, S., \& Abel, T. (2016). Just a subtle difference? Findings from a systematic review on definitions of nutrition literacy and food literacy. Health Promotion International. https://doi.org/10.1093/heapro/daw084

Lane, M. B. (2005). Public Participation in Planning: an intellectual history. Australian Geographer, 36(3), 283-299. https://doi.org/10.1080/00049180500325694

Lao, A. (2016). Planning Visually: Design that takes plans off the shelf and into the public. School of Community \& Regional Planning, UBC.

Liu, T. (2017). An Urban Planning Approach to Digital Inequality. Ryerson University.

Maximum City. (2016). Maximum City Research Report 2016. Maximum City.

Miller, J. (1983). Scientific Literacy: A Conceptual and Empirical Review. Daedalus, 112(2), $29-48$.

Millner, H. (2002). Civic Literacy: How Informed Citizens Make Democracy Work. Hanover, NH: University Press of New England.

Ministry of Municipal Affairs. (2017, May 16). Giving Communities a Stronger Voice In Development. Retrieved April 9, 2018, from https://news.ontario.ca/mah/en/2017/05/giving-communities-a-strongervoice-in-development.html.

Nabatchi, T., \& Leighninger, M. (2015). Public Participation for 21st Century Democracy. New Jersey: John Wiley \& Sons, Inc.

National Research Center. (2016, November 18). How to Avoid Survey Fatigue. Retrieved March 12, 2018, from https://www.n-r-c.com/how-to-avoid-survey-fatigue/

Neuman, W. L., \& Robson, K. (2015). Basics of Social Research: Qualitative and Quantitative Approaches (3rd Canadian Edition). Toronto: Pearson Canada Inc.

Nutbeam, D. (2000). Health Literacy as a Public Health Goal: A Challenge for Contemporary Health Education and Communication Strategies into the 21st Century. Health Promotion International, 15(3), 259-267. https://doi.org/10.1093/heapro/15.3.259

Nutbeam, D. (2008). The evolving concept of health literacy. Social Science \& Medicine, 67, 2072-2078. https://doi.org/10.1016/j.socscimed.2008.09.050 
Nutbeam, D. (2015). Defining, measuring and improving health literacy. HEP, 42(4), 450-456.

OECD. (2003). The PISA 2003 Assessment Framework— Mathematics, Reading, Science and Problem Solving Knowledge and Skills. Paris: OECD. Retrieved from http://www.oecdilibrary.org.ezproxy.lib.ryerson.ca/docserver/download/9603051e.pdf?expires=1519437053\&id=id\&accn $\underline{\text { ame=guest\&checksum=BC419EA9B71E360ADDAE2764A35596B9 }}$

OECD. (n.d.). Adult Literacy. Retrieved February 23, 2018, from http://www.oecd.org/education/innovationeducation/adultliteracy.htm

OECD INFE. (2011). Measuring Financial Literacy: Questionnaire and Guidance Notes for Conducting an Internationally Comparable Survey of Financial Literacy. OECD. Retrieved from https://www.oecd.org/finance/financial-education/49319977.pdf

Ontario Professional Planners Institute. (n.d.-a). Professional Code of Practice. Retrieved March 12, 2018, from http://ontarioplanners.ca/Knowledge-Centre/Professional-Code-of-Practice

Ontario Professional Planners Institute. (n.d.-b). World Town Planning Day. Retrieved March 19, 2018, from http://ontarioplanners.ca/Knowledge-Centre/Programs-Events/World-Town-Planning-Day

Osborne, R., Batterham, R., Elsworth, G., Hawkins, M., \& Buchbinder, R. (2013). The grounded psychometric development and initial validation of the Health Literacy Questionnaire (HLQ). BMC Public Health, 13(658). Retrieved from http://www.biomedcentral.com/1471-2458/13/658

People Plan Toronto. (n.d.-a). How We Talk About How We Build. Retrieved March 2, 2018, from http://peopleplantoronto.org:81/files/ppt_planning_glossary.pdf

People Plan Toronto. (n.d.-b). People Plan Toronto. Retrieved March 19, 2018, from http://peopleplantoronto.org/

People Plan Toronto. (n.d.-c). Planning Resource Centre. Retrieved March 11, 2018, from http://peopleplantoronto.org/work/cprc

Remund, D. L. (2010). Financial Literacy Explicated: The Case for a Clearer Definition in an Increasingly Complex Economy. Journal of Consumer Affairs, 44(2), 276-295. https://doi.org/10.1111/j.1745$\underline{6606.2010 .01169 . x}$ 
Silk, K. J., Sherry, J., Winn, B., Keesecker, N., Horodynski, M. A., \& Sayir, A. (2008). Increasing Nutrition Literacy: Testing the Effectiveness of Print, Web site, and Game Modalities. Journal of Nutrition Education and Behavior, 40(1), 3-10.

Stibbe, A. (Ed.). (2009). The Handbook of Sustainability Literacy: Skills for a Changing World. UK: Green Books Ltd.

The Planning Clinic. (n.d.). the-planning-clinic | MISSION + PRINCIPLES. Retrieved March 19, 2018, from http://www.theplanningclinic.org/principles

Toronto City Planning. (2013). 2013-2018 City Planning Strategic Plan. Toronto. Retrieved from https://www1.toronto.ca/City\%20Of\%20Toronto/City\%20Planning/Home/Files/pdf/S/strategicplan.pdf

Toronto City Planning. (2014a). Resident Association Roundtable: Etobicoke District - October 20, 2014 Meeting Summary.

Toronto City Planning. (2014b). Resident Association Roundtable: North York District - October 16, 2014 Meeting Summary.

Toronto City Planning. (2014c). Resident Association Roundtable: Scarborough District - October 14, 2014 Meeting Summary.

Toronto City Planning. (2014d). Resident Association Roundtable: Toronto District - October 21, 2014 Meeting Summary.

Toronto City Planning. (2015). Youth Engagement Strategy - Final Report.

Toronto City Planning. (2016). TOcore Phase 2 Engagement Report. City of Toronto. Retrieved from https://www.toronto.ca/wp-content/uploads/2017/11/91ff-CityPlanning-TOcore-EngagementReportPhase2_web-accessible.pdf

Toronto City Planning. (2017a, November 13). Toronto Planning Review Panel. Retrieved March 19, 2018, from https://www.toronto.ca/city-government/planning-development/outreach-engagement/torontoplanning-review-panel/ 
Toronto City Planning. (2017b, November 16). TOcore: Downtown Stories. Retrieved March 19, 2018, from https://www.toronto.ca/city-government/planning-development/planning-studies-initiatives/tocoreplanning-torontos-downtown/tocore-downtown-stories/

Toronto City Planning. (2018). Street Level: Honest Ed's Redevelopment (Mirvish Village). Retrieved from https://www.youtube.com/watch?v=8ZZ0RyIhZsM

Toronto City Planning. (n.d.-a). Growing Conversations: Getting Involved in City Planning. City of Toronto.

Toronto City Planning. (n.d.-b). What We Heard: Growing Conversations. Retrieved February 22, 2018, from https://www.toronto.ca/city-government/planning-development/outreach-engagement/growingconversations-making-engagement-work/what-we-heard-growing-conversations/

Toronto Women’s City Alliance. (n.d.). Municipal Literacy Toolkit. Toronto Women’s City Alliance. Retrieved from http://www.twca.ca/wp-content/uploads/2016/01/TWCA-Municipal-Literacy-ToolkitTagged.pdf

UNESCO Education Sector. (2004). The Plurality of Literacy and its Implications for Policies and Programmes (Position Paper). Paris: UNESCO.

Vidgen, H. A., \& Gallegos, D. (2014). Defining food literacy and its components, 76, 50-59.

Ward Mather, L. (2014). Civic Crafting: The Potential of Minecraft for Municipal Civic Engagement. Ryerson University.

Web Centre for Social Research Methods. (n.d.). Social Research Methods - Knowledge Base - Home. Retrieved March 11, 2018, from http://www.socialresearchmethods.net/kb/index.php

Wen, J. R., \& Shih, W. L. (2008). Exploring the information literacy competence standards for elementary and high school teachers. Computers \& Education, 50, 787-806.

Whittemore, A. H. (2015). How Planners Use Planning Theory. Retrieved March 20, 2018, from https://www.planetizen.com/node/73570/how-planners-use-planning-theory

World Health Organization. (n.d.). Track 2: Health literacy and health behaviour. Retrieved February 23, 2018, from http://www.who.int/healthpromotion/conferences/7gchp/track2/en/

Zaller, J. R. (1992). The Nature and Origins of Mass Opinion. Cambridge: Cambridge University Press. 
Zarcadoolas, C., Pleasant, A. F., \& Greer, D. S. (2006). Advancing health literacy: a framework for understanding and action (1st ed.). San Francisco, CA: Jossey-Bass. 


\section{Appendix A - List of Participants Interviewed}

\begin{tabular}{|c|c|}
\hline $\begin{array}{l}\text { Participant } \\
\quad \#\end{array}$ & Experience (Anonymized) \\
\hline 1. & $\begin{array}{l}\text { Executive director of Toronto-based non-profit organization specializing in planning } \\
\text { consulting and local capacity building }\end{array}$ \\
\hline 2. & $\begin{array}{l}\text { Constituency assistant to local councilor in a rapidly-intensifying downtown ward in } \\
\text { Toronto }\end{array}$ \\
\hline 3. & $\begin{array}{l}\text { Public policy manager at US-based non-profit organization specializing in civic and } \\
\text { planning research, education and advocacy work }\end{array}$ \\
\hline 4. & $\begin{array}{l}\text { Associate at Toronto-based firm specialized in designing and delivering consultation } \\
\text { and engagement processes }\end{array}$ \\
\hline 5. & Chair of Toronto-based community association \\
\hline 6. & Stakeholder engagement specialist at the City of Toronto \\
\hline 7. & Land use planner at private firm \\
\hline 8. & $\begin{array}{l}\text { Former director of community and stakeholder relations at provincial organization; } \\
\text { founder of Toronto-based community association }\end{array}$ \\
\hline 9. & $\begin{array}{l}\text { Former city planner in municipality outside Ontario and research manager at Toronto- } \\
\text { based non-profit organization specializing in civic and planning research, education and } \\
\text { advocacy work }\end{array}$ \\
\hline 10. & $\begin{array}{l}\text { Senior associate at Toronto-based firm specialized in designing and delivering } \\
\text { consultation and engagement processes }\end{array}$ \\
\hline 11. & $\begin{array}{l}\text { Senior associate at Toronto-based firm specialized in designing and delivering } \\
\text { consultation and engagement processes }\end{array}$ \\
\hline 12. & $\begin{array}{l}\text { Project coordinator and engagement specialist at Toronto-based incorporated social } \\
\text { enterprise specialized in community engagement and education }\end{array}$ \\
\hline 13. & $\begin{array}{l}\text { Program manager at US-based non-profit organization specializing in civic and } \\
\text { planning research, education and advocacy work }\end{array}$ \\
\hline 14. & Community planner at the City of Toronto \\
\hline 15. & $\begin{array}{l}\text { Associate at Toronto-based firm specialized in designing and delivering consultation } \\
\text { and engagement processes }\end{array}$ \\
\hline
\end{tabular}




\section{Appendix B - Questions Asked in Interviews}

\section{Part A: The concept and relevance of planning literacy}

1. Have you come across the term "planning literacy" before? If so, what context?

2. How would you define "planning literacy"? What does it mean to be "planning literate"?

3. What is the relationship between planning literacy and local democratic processes?

\section{Part B: Planning education and literacy tools}

4. Could you tell me about the work you do/your organization does to improve public planning literacy?

5. Are you aware of any innovative or effective educational initiatives or organizations that aim to improve public planning literacy?

6. What organizations, in your view, would benefit from knowledge of public planning literacy levels?

\section{Part C: A survey to measure planning literacy in Toronto}

Note: If you have limited experience in the Toronto context, please reference the jurisdiction you are most familiar with.

7. To your knowledge, what tools (i.e. surveys or questionnaires) exist for measuring planning literacy in Toronto or beyond?

8. Have you measured planning literacy in your line of work? How, and in what context? Any information regarding methodology, outcomes, challenges and lessons learned would be appreciated.

9. What kind of planning knowledge should every citizen of Toronto ideally be equipped with? For example, knowledge of specific terms/concepts, key projects/reports/policies (e.g. Official Plan), processes?

10. What type of information is important to a planner in Toronto who wishes to improve public engagement and who would like to understand local planning literacy levels?

11. Are there any questions that are "standard" to a City of Toronto survey (i.e. certain demographic questions)? [Note: For select participants only]

12. Do you have any advice on how the results of a tool to measure planning literacy could be made as useful as possible to planners?

13. Would you be interested in reviewing and providing input on a draft of the planning literacy survey I am creating, once it is available? 


\section{Appendix C - Planning “Jargon"}

A public community consultation meeting hosted by City Planning regarding a development application was attended in Spring 2017. The following terms or phrases were used by the city planner during the meeting:

- Freehold

- FSI

- “Conformity with PPS and Growth Plan”

- Open space character

- Natural heritage

- Massing

- Density

- At grade

- Parkland levies

- Infill

- $\quad$ Section 37

- Complete community

- Community council

- Public realm

- Frontage

- Setback

- $\quad$ Aperture

A participant in City Planning highlighted several terms that he thinks planners overuse. They are as follows (terms that overlapped with the above list have been removed):

- $\quad$ Site and area specific policy

- Built form

- Public realm

- Land use category

- Mixed use development

- Angular plane

- Zone category

- Liveability

- Public interest

- $\quad$ Tall building 


\section{$\underline{\text { Appendix D - Precedent Literacy Questionnaires }}$}

\section{A. Krause et al. (2016; 2018) Short Food Literacy Questionnaire (SFLQ)}

Table 4 Working definition of nutrition-specific health literacy (Krause et al., 2016)

\begin{tabular}{|c|c|c|}
\hline & Nutrition-specific health literacy themes & Form of Literacy \\
\hline 1. & $\begin{array}{l}\text { Ability to acquire information about food, food preparation and } \\
\text { the influence of nutrition on health }\end{array}$ & \multirow{5}{*}{ Functional } \\
\hline 2. & $\begin{array}{l}\text { Ability to understand information about food (e.g. nutrition } \\
\text { labelling on food) }\end{array}$ & \\
\hline 3. & $\begin{array}{l}\text { "Having knowledge" of: } \\
\text { • healthy nutrition (what does healthy nutrition involve?) } \\
\text { • nutritional recommendations, food preparation, salt } \\
\text { content }\end{array}$ & \\
\hline 4. & $\begin{array}{l}\text { Ability to prepare a balanced meal in accordance with available } \\
\text { resources and financial means }\end{array}$ & \\
\hline 5. & Ability to make a healthy choice & \\
\hline 6. & Ability to talk about nutrition with friends and family & \multirow[b]{2}{*}{ Interactive } \\
\hline 7. & $\begin{array}{l}\text { Ability to apply information one has read about nutrition to one's } \\
\text { own situation }\end{array}$ & \\
\hline 8. & Ability to assess nutritional information from different sources & \multirow{5}{*}{ Critical } \\
\hline 9. & $\begin{array}{l}\text { Ability to assess whether a food contributes to healthy nutrition; } \\
\text { ability to distinguish between healthy and less healthy options }\end{array}$ & \\
\hline 10. & Ability to understand the connection between nutrition and health & \\
\hline 11. & Ability to advocate health promoting conditions & \\
\hline 12. & $\begin{array}{l}\text { Ability to understand nutrition and health related topics in the } \\
\text { larger societal context }\end{array}$ & \\
\hline
\end{tabular}

Table 5 Final SFLQ with corresponding themes (Krause et al., 2016; Krause et al., 2018)

\begin{tabular}{|c|c|c|}
\hline & Item & Response Choices \\
\hline & Functional (Themes 1-5) & \\
\hline 1. & $\begin{array}{l}\text { When I have questions on healthy nutrition, I know where I can } \\
\text { find information on this issue. (Theme 1) }\end{array}$ & $\begin{array}{l}\text { Disagree strongly - } 1 \text { to } \\
\text { Agree strongly - } 4 \text {; I do } \\
\text { not have experience with } \\
\text { these issues - } 0\end{array}$ \\
\hline 2. & $\begin{array}{l}\text { In general, how well do you understand the following types of } \\
\text { nutritional information? } \\
\text { (A) Nutrition information leaflets } \\
\text { (B) Food label information } \\
\text { (C) TV or radio program on nutrition } \\
\text { (D) Oral recommendations regarding nutrition from professionals. } \\
\text { (E) Nutrition advice from family members or friends (Theme 2) }\end{array}$ & $\begin{array}{l}\text { Very bad - } 1 \text { to Very good - } \\
5 \text {; I do not make use } \\
\text { of this kind of information - } \\
0\end{array}$ \\
\hline 3. & How familiar are you with the Swiss Food Pyramid? (Theme 3) & $\begin{array}{l}\text { Very bad - } 1 \text { to Very good - } \\
5\end{array}$ \\
\hline 4. & $\begin{array}{l}\text { A balanced meal is composed of different foods. [...] } \\
\text { Please check the image that best represents the proportion of a } \\
\text { balanced meal. (Theme 3) }\end{array}$ & $\begin{array}{l}\text { (removed in Krause et al., } \\
\text { 2018) }\end{array}$ \\
\hline 5. & $\begin{array}{l}\text { I know the official Swiss recommendations about fruit and } \\
\text { vegetable consumption. (Theme 3) }\end{array}$ & $\begin{array}{l}\text { Disagree strongly - } 1 \text { to } \\
\text { Agree strongly - } 4\end{array}$ \\
\hline
\end{tabular}




\begin{tabular}{|c|c|c|}
\hline 6. & $\begin{array}{l}\text { I know the official Swiss recommendations about salt intake. } \\
\text { (Theme 3) }\end{array}$ & $\begin{array}{l}\text { Disagree strongly - } 1 \text { to } \\
\text { Agree strongly - } 4\end{array}$ \\
\hline 7. & $\begin{array}{l}\text { Think about a usual day: how easy or difficult is it for you to } \\
\text { compose a balanced meal at home? (Theme } 4 / 5 \text { ) }\end{array}$ & $\begin{array}{l}\text { Very hard - } 1 \text { to very easy - } \\
4 \text {; not applicable - } 0\end{array}$ \\
\hline \multirow[t]{2}{*}{8.} & $\begin{array}{l}\text { And if you are eating out on a usual day, in a restaurant, canteen, } \\
\text { etc.: how easy or difficult is it for you to compose a balanced } \\
\text { meal? (Theme 5) }\end{array}$ & $\begin{array}{l}\text { (removed in Krause et al., } \\
\text { 2018) }\end{array}$ \\
\hline & Interactive (Themes 6-7) & \\
\hline 9. & $\begin{array}{l}\text { In the past, how often were you able to help your family members } \\
\text { or a friend if they had questions concerning nutritional issues? } \\
\text { (Theme 6) }\end{array}$ & $\begin{array}{l}1 \text { - Never to always - } 5 \text {; } \\
\text { there have never been } \\
\text { any questions - } 0\end{array}$ \\
\hline 10. & $\begin{array}{l}\text { In the past, when you have had questions concerning nutritional } \\
\text { issues, how often did you get information and advice from others } \\
\text { (families and friends)? (Theme 6) }\end{array}$ & $\begin{array}{l}\text { (removed in Krause et al., } \\
\text { 2018) }\end{array}$ \\
\hline \multirow[t]{2}{*}{11.} & $\begin{array}{l}\text { There is a lot of information available on healthy nutrition today. } \\
\text { How well do you manage to choose the information relevant to } \\
\text { you? (Theme 7) }\end{array}$ & $\begin{array}{l}\text { Very bad - } 1 \text { to Very good - } \\
5 \text {; I have not been } \\
\text { interested in these issues - } 0\end{array}$ \\
\hline & Critical (Themes 8-12) & \\
\hline 12. & $\begin{array}{l}\text { How easy is it for you to judge if media information on nutritional } \\
\text { issues can be trusted? (Theme 8) }\end{array}$ & $\begin{array}{l}\text { Very difficult - } 1 \text { to very } \\
\text { easy - } 4\end{array}$ \\
\hline 13. & $\begin{array}{l}\text { Commercials often relate foods with health. How easy is it for you } \\
\text { to judge if the presented associations are appropriate or not? } \\
\text { (Theme } 8 \text { ) }\end{array}$ & $\begin{array}{l}\text { Very hard - } 1 \text { to very easy - } \\
4\end{array}$ \\
\hline 14. & $\begin{array}{l}\text { How easy is it for you to evaluate if a specific food is relevant for } \\
\text { a healthy diet? (Theme 9) }\end{array}$ & $\begin{array}{l}\text { Very hard - } 1 \text { to very easy - } \\
4\end{array}$ \\
\hline 15. & $\begin{array}{l}\text { How easy is it for you to evaluate the longer-term impact of your } \\
\text { dietary habits on your health? (Theme 10) }\end{array}$ & $\begin{array}{l}\text { Very hard - } 1 \text { to very easy - } \\
4\end{array}$ \\
\hline 16. & $\begin{array}{l}\text { How easy is it for you to advocate a healthy nutrition? } \\
\text { (A) In your family } \\
\text { (B) In your circle of friends and acquaintances } \\
\text { (C) At work } \\
\text { (D) In your neighborhood (e.g. residential area, community) } \\
\text { (Theme 10) }\end{array}$ & $\begin{array}{l}\text { (removed in Krause et al., } \\
\text { 2018) }\end{array}$ \\
\hline
\end{tabular}

Table 6 Participant demographic information (Krause et al., 2018)

\begin{tabular}{|l|l|l|}
\hline & \multicolumn{1}{|c|}{ Item } & \multicolumn{1}{|c|}{ Response Choices } \\
\hline 1. & Gender & Male \\
\hline 2. & Age & Female \\
& & $15-34$ years \\
& & $35-54$ years \\
\hline 3. & Education & 55-65 years \\
\hline 4. & Household structure & Primary or secondary \\
& & Tertiary \\
& & Single-person household \\
& & Couple without children \\
& & Couple with children \\
& & One-parent household \\
& & Adult who lives with parent/s \\
\end{tabular}




\begin{tabular}{|l|l|l|}
\hline 5. & Employment & Mostly manual work \\
& & Mostly sedentary work \\
\hline 6. & Self-rated health & Very bad \\
& & Bad \\
& & Intermediate \\
& & Good \\
& Very good \\
\hline
\end{tabular}

\section{B. OECD INFE (2011) Financial literacy questionnaire (FinLQ)}

Table 7 Four themes of financial literacy and corresponding core questions (Kempson, 2009)

\section{Theme \#1: Day-to-day money management}

Financial Control

1. Whether people have a budget

2. Whether and how people keep records of their spending

3. How accurately people know how much money they have for daily living costs

Making ends meet

4. How often run short of money and actions taken when money runs out

5. How easy it is to keep up with payments on bills and other financial commitments

Attitude questions on approaches to financial management

6. I am impulsive and buy things even when I can't really afford them

7. I buy things on credit rather than waiting and saving up

8. I am organised with regard to managing money

9. I am more of a saver than a spender

\section{Theme \#2: Financial planning}

Provision for an emergency

1. How would meet daily living costs if lost the main wage (or had a substantial drop in income if no income from employment) for three months

2. How would meet an unexpected expense of a set multiple of monthly income

Savings/insurance held

3. How much money is put aside in savings for an emergency

4. Types of insurance held

Attitudes to financial planning

5. I live for today and let tomorrow take care of itself

6. I find it more satisfying to spend money than save it for the long term

7. I save money for a rainy day

Theme \#3: Choosing appropriate products

1. Whether people shop around before buying financial products

2. What product features were considered when making a recent purchase (ideally the most complex product they have bought

Theme \#4: Financial knowledge and understanding

Note: These questions are all recommended as optional rather than core questions as in all instances the situation varies widely between countries and it is not possible to design a generic question (OECD INFE, 2011, 7).

Keeping up-to-date with financial matters 
1. What people monitor and how often, and

2. The information sources they use to do so

Understanding of key concepts

3. Ability to weigh up risk and return

4. Understanding of inflation

5. Understanding of interest rates

Knowledge of financial products and services

6. Knowledge of key features of products held

7. General attitude statement _I know enough about financial products to choose ones that meet my needs

Other areas considered, include:

8. Knowledge of financial products generally

9. Knowledge of consumer rights

10. Knowledge of how to get redress

Table 8 OECD INFE (2011) FinLQ Core Questionnaire

Note: The FinLQ is intended to be administered in-person. Some instructions and clarifying notes to interviewers in the original FinLQ were left out in the below chart. Coding and scoring methodology is also not recorded below.

\begin{tabular}{|c|c|c|}
\hline & Item & Response Choices \\
\hline & Background Questions & \\
\hline 1. & $\begin{array}{l}\text { [Interviewer to record } \\
\text { participant gender] }\end{array}$ & $\begin{array}{l}\text { Male } \\
\text { Female }\end{array}$ \\
\hline 2. & $\begin{array}{l}\text { Which of these best describes } \\
\text { the community you live in? }\end{array}$ & $\begin{array}{l}\text { a) A village, hamlet or rural area (fewer than } 3000 \text { people) } \\
\text { b) A small town (3000 to about } 15000 \text { people) } \\
\text { c) A town (15000 to about } 100000 \text { people) } \\
\text { d) A city (100 } 000 \text { to about } 1000000 \text { people) } \\
\text { e) A large city (with over } 1000000 \text { people) } \\
\text { f) Don't know } \\
\text { g) Refused }\end{array}$ \\
\hline 3. & $\begin{array}{l}\text { [Interviewer to record the } \\
\text { language used in the } \\
\text { interview] }\end{array}$ & [Applicable language] \\
\hline 4. & $\begin{array}{l}\text { Please could you tell me your } \\
\text { marital status? }\end{array}$ & $\begin{array}{l}\text { Married } \\
\text { Single } \\
\text { Separated/divorced } \\
\text { Living with partner } \\
\text { Widowed } \\
\text { Don't know } \\
\text { Refused }\end{array}$ \\
\hline 5. & $\begin{array}{l}\text { How many children under the } \\
\text { age of } 18 \text { live with you, in } \\
\text { your household? }\end{array}$ & $\begin{array}{l}\text { [Number of children] } \\
\text { Don't know } \\
\text { Refused }\end{array}$ \\
\hline 6. & $\begin{array}{l}\text { How many people aged } 18 \\
\text { and over live with you, in } \\
\text { your household. Please do not }\end{array}$ & $\begin{array}{l}\text { [Number of adults] } \\
\text { Don't know } \\
\text { Refused }\end{array}$ \\
\hline
\end{tabular}




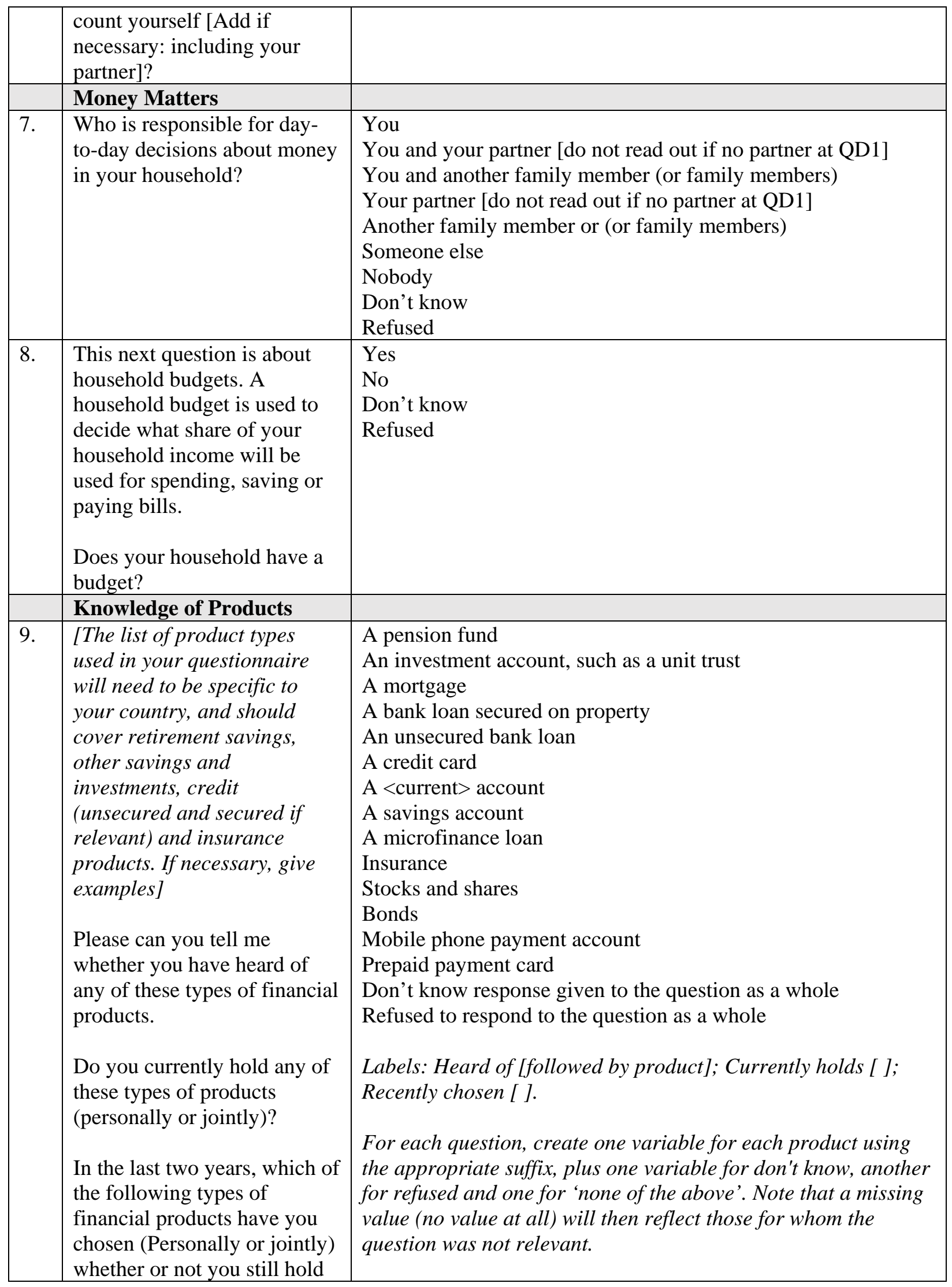




\begin{tabular}{|c|c|c|}
\hline & $\begin{array}{l}\text { them...Please do not include } \\
\text { products that were renewed } \\
\text { automatically. }\end{array}$ & $\begin{array}{l}\text { For example, the first question will have one variable named } \\
\text { QC1_a_1 and labelled Heard of a Pension Fund. This variable } \\
\text { will take the value } 0 \text { if respondent says No, and } 1 \text { if respondent } \\
\text { says Yes. }\end{array}$ \\
\hline 10. & $\begin{array}{l}\text { [Question QC2 omitted for } \\
\text { lack of relevance] }\end{array}$ & N/A \\
\hline 11. & $\begin{array}{l}\text { Which sources of information } \\
\text { do you feel most influenced } \\
\text { your decision about which } \\
\text { [product] to take out? }\end{array}$ & $\begin{array}{l}1 \text { Product-specific information } \\
\text { a) Unsolicited information sent through the post } \\
\text { b) Information picked up in a branch } \\
\text { c) Product specific information found on the internet } \\
\text { d) Information from sales staff of the firm providing the } \\
\text { products (including quotes) } \\
\mathbf{2} \text { Best buy guidance } \\
\text { e) Best-buy tables in financial pages of newspapers/magazines } \\
\text { f) Best-buy information found on the internet } \\
\text { g) Specialist magazines/publications } \\
\text { h) Recommendation from independent financial adviser or } \\
\text { broker } \\
\text { 3 General advice } \\
\text { i) Advice of friends/relatives (not working in the financial } \\
\text { services industry) } \\
\text { j) Advice of friends/relatives (who work in the financial services } \\
\text { industry) } \\
\text { k) Employer's advice } \\
\text { 4 Media coverage } \\
\text { l) Newspaper articles } \\
\text { m) Television or radio programmes } \\
\mathbf{5} \text { Adverts } \\
\text { n) Newspaper adverts } \\
\text { o) Television adverts } \\
\text { p) Other advertising } \\
\mathbf{6} \text { Other } \\
\text { q) My own previous experience } \\
\text { r) Other source } \\
\text { s) Don’t know } \\
\text { t) Not applicable (no recent choice) } \\
\text { u) Refused }\end{array}$ \\
\hline & General money questions & \\
\hline 12. & $\begin{array}{l}\text { Before I buy something I } \\
\text { carefully consider whether I } \\
\text { can afford it }\end{array}$ & $\begin{array}{l}\text { Completely agree, 2, 3, 4, completely disagree } \\
\text { (Don't know, refused) }\end{array}$ \\
\hline 13. & $\begin{array}{l}\text { I tend to live for today and let } \\
\text { tomorrow take care of itself }\end{array}$ & $\begin{array}{l}\text { Completely agree, 2, 3, 4, completely disagree } \\
\text { (Don't know, refused) }\end{array}$ \\
\hline
\end{tabular}




\begin{tabular}{|c|c|c|}
\hline 14. & $\begin{array}{l}\text { I find it more satisfying to } \\
\text { spend money than to save it } \\
\text { for the long term }\end{array}$ & $\begin{array}{l}\text { Completely agree, 2, 3, 4, completely disagree } \\
\text { (Don’t know, refused) }\end{array}$ \\
\hline 15. & I pay my bills on time & $\begin{array}{l}\text { Completely agree, 2, 3, 4, completely disagree } \\
\text { (Don't know, refused) }\end{array}$ \\
\hline 16. & $\begin{array}{l}\text { I am prepared to risk some of } \\
\text { my own money when saving } \\
\text { or making an investment }\end{array}$ & $\begin{array}{l}\text { Completely agree, 2, 3, 4, completely disagree } \\
\text { (Don't know, refused) }\end{array}$ \\
\hline 17. & $\begin{array}{l}\text { I keep a close personal watch } \\
\text { on my financial affairs }\end{array}$ & $\begin{array}{l}\text { Completely agree, } 2,3,4 \text {, completely disagree } \\
\text { (Don't know, refused) }\end{array}$ \\
\hline 18. & $\begin{array}{l}\text { I set long term financial goals } \\
\text { and strive to achieve them }\end{array}$ & $\begin{array}{l}\text { Completely agree, 2, 3, 4, completely disagree } \\
\text { (Don't know, refused) }\end{array}$ \\
\hline 19. & Money is there to be spent & $\begin{array}{l}\text { Completely agree, } 2,3,4 \text {, completely disagree } \\
\text { (Don't know, refused) }\end{array}$ \\
\hline 20. & $\begin{array}{l}\text { Sometimes people find that } \\
\text { their income does not quite } \\
\text { cover their living costs. In the } \\
\text { last } 12 \text { months, has this } \\
\text { happened to you? }\end{array}$ & $\begin{array}{l}\text { Yes } \\
\text { No } \\
\text { Don't know } \\
\text { Not applicable (I don't have any personal income) } \\
\text { Refused }\end{array}$ \\
\hline 21. & $\begin{array}{l}\text { (Re: question above) What } \\
\text { did you do to make ends meet } \\
\text { the last time this happened? }\end{array}$ & $\begin{array}{l}\text { 1 Existing resources } \\
\text { a) Draw money out of savings or transfer savings into current } \\
\text { account } \\
\text { b) Cut back on spending, spend less, do without } \\
\text { c) Sell something that I own } \\
2 \text { Creating resources } \\
\text { d) Work overtime, earn extra money } \\
\text { 3 Access credit by using existing contacts or resources } \\
\text { e) Borrow food or money from family or friends } \\
\text { f) Borrow from employer/salary advance } \\
\text { g) Pawn something that I own } \\
\text { h) Take a loan from my savings and loans clubs } \\
\text { i) Take money out of a flexible mortgage account } \\
\text { j) Apply for loan/withdrawal on pension fund } \\
\text { 4 Borrow from existing credit line } \\
\text { k) Use authorised, arranged overdraft or line of credit } \\
\text { l) Use credit card for a cash advance or to pay bills/buy food } \\
5 \\
\text { 5 Access new line of credit } \\
\text { m) Take out a personal loan from a financial service provider } \\
\text { (including bank, credit union or microfinance) } \\
\text { n) Take out a payday loan } \\
\text { o) Take out a loan from an informal provider/moneylender } \\
\text { 6 Fall behind/ go beyond arranged amount } \\
\text { p) Use unauthorised overdraft } \\
\text { q) Pay my bills late; miss payments }\end{array}$ \\
\hline
\end{tabular}




\begin{tabular}{|c|c|c|}
\hline & & $\begin{array}{l}7 \text { Other responses } \\
\text { r) Other } \\
\text { s) Don't know } \\
\text { t) Refused }\end{array}$ \\
\hline 22. & $\begin{array}{l}\text { In the past } 12 \text { months have } \\
\text { you been [personally] saving } \\
\text { money in any of the } \\
\text { following ways, whether or } \\
\text { not you still have the money? }\end{array}$ & $\begin{array}{l}\text { Saving cash at home or in your wallet } \\
\text { Building up a balance of money in your bank account } \\
\text { Paying money into a savings account } \\
\text { Giving money to family to save on your behalf } \\
\text { Saving in <an informal savings club> } \\
\text { Buying financial investment products, other than pension funds } \\
\text { [give examples such as bonds, investment trusts, stocks and } \\
\text { shares] } \\
\text { Or in some other way (including remittances, buying livestock } \\
\text { or property) } \\
\text { Has not been actively saving (including I don't save/I have no } \\
\text { money to save) } \\
\text { Don't know } \\
\text { refused }\end{array}$ \\
\hline 23. & $\begin{array}{l}\text { If you lost your main source } \\
\text { of income, how long could } \\
\text { you continue to cover living } \\
\text { expenses, without borrowing } \\
\text { any money or < moving } \\
\text { house }>\text { ? }\end{array}$ & $\begin{array}{l}\text { Less than a week } \\
\text { At least a week, but not one month } \\
\text { At least one month, but not three months } \\
\text { At least three months, but not six months } \\
\text { More than six months. } \\
\text { Don't know } \\
\text { Refused }\end{array}$ \\
\hline & Skill-testing questions & \\
\hline 24. & $\begin{array}{l}\text { Imagine that five }<\text { brothers }> \\
\text { are given a gift of } \$ 1,000 \text {. If } \\
\text { the }<\text { brothers }>\text { have to share } \\
\text { the money equally how much } \\
\text { does each one get? }\end{array}$ & $\begin{array}{l}200 \text { (correct answer) } \\
\text { Don’t know } \\
\text { Refused } \\
\text { Irrelevant answer }\end{array}$ \\
\hline 25. & $\begin{array}{l}\text { Now imagine that the } \\
<\text { brothers }>\text { have to wait for } \\
\text { one year to get their share of } \\
\text { the } \$ 1,000 \text { and inflation stays } \\
\text { at X percent. In one year’s } \\
\text { time will they be able to buy: }\end{array}$ & $\begin{array}{l}\text { More with their share of the money than they could today } \\
\text { The same amount } \\
\text { Or, less than they could buy today (general correct response) } \\
\text { It depends on the types of things that they want to buy } \\
\text { Don't know } \\
\text { Refused } \\
\text { Irrelevant answer }\end{array}$ \\
\hline 26. & $\begin{array}{l}\text { You lend } \$ 25 \text { to a friend one } \\
\text { evening and he gives you } \$ 25 \\
\text { back the next day. How much } \\
\text { interest has he paid on this } \\
\text { loan? }\end{array}$ & $\begin{array}{l}0 \text { (correct response) } \\
\text { Don't know } \\
\text { Refused } \\
\text { Irrelevant answer }\end{array}$ \\
\hline 27. & $\begin{array}{l}\text { Suppose you put } \$ 100 \text { into a } \\
<\text { no fee> savings account } \\
\text { with a guaranteed interest rate } \\
\text { of } 2 \% \text { per year. You don’t } \\
\text { make any further payments } \\
\text { into this account and you } \\
\text { don't withdraw any money. }\end{array}$ & $\begin{array}{l}102 \text { (correct response) } \\
\text { Don’t know } \\
\text { Refused } \\
\text { Irrelevant answer }\end{array}$ \\
\hline
\end{tabular}




\begin{tabular}{|c|c|c|}
\hline & $\begin{array}{l}\text { How much would be in the } \\
\text { account at the end of the first } \\
\text { year, once the interest } \\
\text { payment is made? }\end{array}$ & \\
\hline 28. & $\begin{array}{l}\text { and how much would be in } \\
\text { the account at the end of five } \\
\text { years [add if necessary: } \\
\text { remembering there are no } \\
\text { fees]? Would it be: }\end{array}$ & $\begin{array}{l}\text { More than } \$ 110 \text { (correct response) } \\
\text { Exactly } \$ 110 \\
\text { Less than } \$ 110 \\
\text { Or is it impossible to tell from the information given } \\
\text { Don’t know } \\
\text { Refused } \\
\text { Irrelevant answer }\end{array}$ \\
\hline 29. & $\begin{array}{l}\text { An investment with a high } \\
\text { return is likely to be high risk }\end{array}$ & $\begin{array}{l}\text { True (correct response) } \\
\text { False } \\
\text { Don't know } \\
\text { Refused }\end{array}$ \\
\hline 30. & $\begin{array}{l}\text { High inflation means that the } \\
\text { cost of living is increasing } \\
\text { rapidly }\end{array}$ & $\begin{array}{l}\text { True (correct response) } \\
\text { False } \\
\text { Don't know } \\
\text { Refused }\end{array}$ \\
\hline 31. & $\begin{array}{l}\text { It is usually possible to } \\
\text { reduce the risk of investing in } \\
\text { the stock market by buying a } \\
\text { wide range of stocks and } \\
\text { shares. }\end{array}$ & $\begin{array}{l}\text { True (correct response) } \\
\text { False } \\
\text { Don't know } \\
\text { Refused }\end{array}$ \\
\hline 32. & $\begin{array}{l}\text { It is less likely that you will } \\
\text { lose all of your money if you } \\
\text { save it in more than one } \\
\text { place. }\end{array}$ & $\begin{array}{l}\text { True (correct response) } \\
\text { False } \\
\text { Don't know } \\
\text { Refused }\end{array}$ \\
\hline & Household information & \\
\hline 33. & $\begin{array}{l}\text { Please could you tell me how } \\
\text { old you are, currently? } \\
\text { OR } \\
\text { Would you \{instead }\} \text { tell me } \\
\text { which of these age bands you } \\
\text { fall into? }\end{array}$ & $\begin{array}{l}\text { [Record age] } \\
\text { OR } \\
18-19 \\
20-29 \\
30-39 \\
40-49 \\
50-59 \\
60-69 \\
70-79 \\
\text { Refused }\end{array}$ \\
\hline 34. & $\begin{array}{l}\text { What is the highest } \\
\text { educational level that you } \\
\text { have attained? }\end{array}$ & $\begin{array}{l}\text { University-level education } \\
\text { Technical/vocational education beyond secondary school level } \\
\text { Complete secondary school } \\
\text { Some secondary school } \\
\text { Complete primary school } \\
\text { Some primary school } \\
\text { No formal education } \\
\text { Refused }\end{array}$ \\
\hline
\end{tabular}




\begin{tabular}{|c|c|c|}
\hline 35. & $\begin{array}{l}\text { And which of these best } \\
\text { describes your current work } \\
\text { situation? }\end{array}$ & $\begin{array}{l}\text { Self employed [work for yourself] } \\
\text { In paid employment [work for someone else] } \\
\text { Looking for work } \\
\text { Looking after the home } \\
\text { Unable to work due to sickness or ill-health } \\
\text { Retired } \\
\text { Student } \\
\text { Not working and not looking for work } \\
\text { Apprentice } \\
\text { Other } \\
\text { Don't know } \\
\text { Refused }\end{array}$ \\
\hline 36. & $\begin{array}{l}\text { [If in work,] how many hours } \\
\text { did you work last week? }\end{array}$ & $\begin{array}{l}\text { [Record value] } \\
\text { Don't know } \\
\text { Refused }\end{array}$ \\
\hline 37. & $\begin{array}{l}\text { People get income from a } \\
\text { wide range of sources. This } \\
\text { might include < wages and } \\
\text { salaries, benefit payments, } \\
\text { pensions or maintenance } \\
\text { payments>. } \\
\text { Considering all of the sources } \\
\text { of income coming into your } \\
\text { household each month, would } \\
\text { you say that your household } \\
\text { income is regular and } \\
\text { reliable? }\end{array}$ & $\begin{array}{l}\text { Yes } \\
\text { No } \\
\text { Don't know } \\
\text { Refused }\end{array}$ \\
\hline 38. & $\begin{array}{l}\text { And finally, can you tell me } \\
\text { which of these categories } \\
\text { your household income } \\
\text { usually falls into [Use as } \\
\text { appropriate: before/after tax]? } \\
\text { [Median income bands to be } \\
\text { created on a per-country } \\
\text { basis] }\end{array}$ & $\begin{array}{l}\text { Up to \$X a month } \\
\text { Between } \$ X \text { and } \$ Y \text { a month } \\
\text { \$Y or more a month } \\
\text { Don't know } \\
\text { Refused }\end{array}$ \\
\hline
\end{tabular}


Appendix E - The Planning Literacy Questionnaire (PLQ)

Attached.

E-1 
The Planning Literacy Questionnaire (PLQ)

\section{INTRODUCTION}

Hello!

Thank you for taking this planning literacy survey. Your input will help the City of Toronto's City Planning division understand what people in Toronto know (or don't know) about planning. We will use the results of the survey to learn how we can communicate better with the public, and where we should focus future public education efforts.

The survey should take up to [10] minutes of your time. There are 7 sections in total. If you are feeling challenged by the questions, don't worry. It means that City Planning has some work to do!

If you have any questions about the survey, feel free to contact [name, position] at [phone number] or [email]. We'll provide this information again at the end of the survey.

[Commentary: The PLQ is intended to be administered online by the City of Toronto. The target audience is adults aged 18+, though anyone can theoretically respond. A hard copy PLQ could also be administered at public consultations or in more neutral public spaces (like a community centre, library or park), to account for digital inequality and the fact that some people may simply prefer those formats.

For questions that have "correct" responses, those responses could be provided after the participant completes each section, to educate and minimize the risk of perpetuating misinformation (Participant \#4).]

\section{SECTION 1 - KEY TERMS}

Below is a list of words or phrases that City Planning uses often. For each word or phrase, would you feel comfortable saying that you know what it means?

Remember: the goal is to help City Planning understand whether people understand the words and phrases that we may take for granted as planners. If you don't know what a word or phrase means, we would like to know.

[Commentary: The number of terms can be cut down.]

\begin{tabular}{|l|l|l|l|}
\hline$\#$ & Statement/Concept/Question & \multicolumn{1}{|c|}{ Response } & Theme \\
\hline 1. & Official Plan & $\begin{array}{l}\text { (a) Yes } \\
\text { (b) No }\end{array}$ & I \\
\hline 2. & Zoning by-law & $\begin{array}{l}\text { (a) Yes } \\
\text { (b) No }\end{array}$ & I \\
\hline 3. & Planning Act & & (b) No \\
\hline 4. & Minor variance & $\begin{array}{l}\text { (a) Yes } \\
\text { (b) No }\end{array}$ & I \\
\hline 5. & Public realm & $\begin{array}{l}\text { (a) Yes } \\
\text { (b) No }\end{array}$ & I \\
\hline 6. & Development application & $\begin{array}{l}\text { (a) Yes } \\
\text { (b) No }\end{array}$ & I \\
\hline
\end{tabular}




\begin{tabular}{|l|l|l|l|}
\hline 7. & Complete community & $\begin{array}{l}\text { (a) Yes } \\
\text { (b) No }\end{array}$ & I \\
\hline 8. & Streetscape & (b) No & I \\
\hline 9. & At grade & $\begin{array}{l}\text { (a) Yes } \\
\text { (b) No }\end{array}$ & I \\
\hline 10. & As of right & $\begin{array}{l}\text { (a) Yes } \\
\text { (b) No }\end{array}$ & I \\
\hline 11. & Setback & $\begin{array}{l}\text { (a) Yes } \\
\text { (b) No }\end{array}$ & I \\
\hline 12. & Built form & $\begin{array}{l}\text { (a) Yes } \\
\text { (b) No }\end{array}$ & I \\
\hline 13. & Frontage & $\begin{array}{l}\text { (a) Yes } \\
\text { (b) No }\end{array}$ & I \\
\hline 14. & Infill development & $\begin{array}{l}\text { (a) Yes } \\
\text { (b) No }\end{array}$ & I \\
\hline 15. & Greenfield development & $\begin{array}{l}\text { (a) Yes } \\
\text { (b) No }\end{array}$ & I \\
\hline 16. & Massing & $\begin{array}{l}\text { (a) Yes } \\
\text { (b) No }\end{array}$ & I \\
\hline 17. & Secondary plan & $\begin{array}{l}\text { (a) Yes } \\
\text { (b) No }\end{array}$ & (a) Yes \\
\hline 18. & Section 37 & $\begin{array}{l}\text { (b) Yes } \\
\text { (b) No }\end{array}$ & I \\
\hline 19. & Land use category & I \\
\hline
\end{tabular}

\section{SECTION 2 - PLANNING LITERACY INITIATIVES}

\section{The below initiatives try to help improve people's planning knowledge and awareness. How familiar are you with them?}

[Commentary: These initiatives were selected because they are all intended to improve planning literacy or public engagement across the City of Toronto. Participants who reviewed this section tended not to respond well to this section - they did not see the connection between the initiatives. Participant \#4 suggested "it's [...] possible that people from different areas of Toronto are more or less exposed to some or all of these initiatives - e.g. some people in Etobicoke may know nothing of TOcore and may also not have opportunities to do Janes Walks in their areas". However, these gaps in knowledge can be accounted for by comparing with respondent forward sortation areas.

I thought it would be interesting to see if people are aware of these initiatives, but this section can be cut.]

\begin{tabular}{|c|l|l|l|}
\hline$\#$ & Statement/Concept/Question & \multicolumn{1}{|c|}{ Response } & Theme \\
\hline 20. & Growing Conversations & $\begin{array}{l}\text { (a) Very familiar } \\
\text { (b) Somewhat familiar } \\
\text { (c) Not familiar at all }\end{array}$ & I \\
\hline 21. & $\begin{array}{l}\text { Planners in Public Spaces } \\
\text { (PiPS) }\end{array}$ & $\begin{array}{l}\text { (a) Very familiar } \\
\text { (b) Somewhat familiar } \\
\text { (c) Not familiar at all }\end{array}$ & I \\
\hline
\end{tabular}




\begin{tabular}{|l|l|l|l|}
\hline 22. & Jane’s Walks & $\begin{array}{l}\text { (a) Very familiar } \\
\text { (b) Somewhat familiar } \\
\text { (c) Not familiar at all }\end{array}$ & I \\
\hline 23. & TOcore avatars & $\begin{array}{l}\text { (a) Very familiar } \\
\text { (b) Somewhat familiar } \\
\text { (c) Not familiar at all }\end{array}$ & I \\
\hline
\end{tabular}

\section{SECTION 3 - PROCESSES AND FINDING INFORMATION}

In this section, we'd like to know how familiar you are with processes that often come up in planning, and whether you know where to find important planning information.

\begin{tabular}{|c|c|c|c|}
\hline \# & Statement/Concept/Question & Response & Theme \\
\hline 24. & $\begin{array}{l}\text { If you wanted to learn details } \\
\text { about a new building } \\
\text { proposed to be built in your } \\
\text { neighbourhood, in which of } \\
\text { the following ways could you } \\
\text { get that information (without } \\
\text { paying someone to do it for } \\
\text { you)? } \\
\text { Pick all the answers that } \\
\text { apply. }\end{array}$ & $\begin{array}{l}\text { (a) Check the Application Information Centre website } \\
\text { [correct response] } \\
\text { (b) Email a Toronto-based municipal lawyer } \\
\text { (c) Contact the Local Planning Appeal Tribunal } \\
\text { (formerly known as the Ontario Municipal Board) } \\
\text { (d) Contact your local councilor [correct response] } \\
\text { (e) Contact the local planner [correct response] } \\
\text { (f) All of the above } \\
\text { (g) None of the above } \\
\text { (h) I'm not sure } \\
\text { *Additional comments }\end{array}$ & II \\
\hline 25. & $\begin{array}{l}\text { If you wanted to learn details } \\
\text { of what was discussed or } \\
\text { decided upon during a City } \\
\text { Council meeting, in which of } \\
\text { the following ways could you } \\
\text { get that information (without } \\
\text { paying someone to do it for } \\
\text { you)? } \\
\text { Pick all the answers that } \\
\text { apply. }\end{array}$ & $\begin{array}{l}\text { (a) Contact your local councilor [correct response] } \\
\text { (b) Check the Toronto Meeting Management } \\
\text { Information System online [correct response] } \\
\text { (c) Contact the Toronto Local Appeal Body } \\
\text { (d) Contact the local planner [correct response] } \\
\text { (e) Email a Toronto-based municipal lawyer } \\
\text { (f) All of the above } \\
\text { (g) None of the above } \\
\text { (h) I'm not sure } \\
\text { *Additional comments }\end{array}$ & II \\
\hline 26. & $\begin{array}{l}\text { If someone asked me to find } \\
\text { the Official Plan, I would } \\
\text { know where to look. }\end{array}$ & $\begin{array}{l}\text { (a) Strongly disagree } \\
\text { (b) Disagree } \\
\text { (c) Agree } \\
\text { (d) Strongly Agree } \\
\text { *Additional comments }\end{array}$ & IV \\
\hline 27. & $\begin{array}{l}\text { If someone asked me to tell } \\
\text { them what kind of growth is } \\
\text { intended for my } \\
\text { neighbourhood under the } \\
\text { Official Plan, I would know } \\
\text { where to look. }\end{array}$ & $\begin{array}{l}\text { (a) Strongly disagree } \\
\text { (b) Disagree } \\
\text { (c) Agree } \\
\text { (d) Strongly Agree } \\
\text { *Additional comments }\end{array}$ & IV \\
\hline 28. & $\begin{array}{l}\text { I heard that City Planning } \\
\text { recently started a planning }\end{array}$ & $\begin{array}{l}\text { (a) Strongly disagree } \\
\text { (b) Disagree }\end{array}$ & IV \\
\hline
\end{tabular}




\begin{tabular}{|l|l|l|l|}
\hline & $\begin{array}{l}\text { study in my neighbourhood. I } \\
\text { know where to get more } \\
\text { information on it. }\end{array}$ & $\begin{array}{l}\text { (c) Agree } \\
\text { (d) Strongly Agree } \\
\text { *Additional comments }\end{array}$ & \\
\hline 29. & $\begin{array}{l}\text { I know how to provide input } \\
\text { on a development proposal. }\end{array}$ & $\begin{array}{l}\text { (a) Disongly disagree } \\
\text { (c) Agree }\end{array}$ & IV \\
& $\begin{array}{ll}\text { (d) Strongly Agree } \\
\text { *Additional comments }\end{array}$ & \\
\hline
\end{tabular}

\section{SECTION 4 - PLAYERS AND THEIR ROLES}

You are more than halfway done - thank you for your answers so far!

In this section, we would learn to know how familiar you are with key players in the planning process.

\begin{tabular}{|c|c|c|c|}
\hline \# & Statement/Concept/Question & Response & Theme \\
\hline 30. & $\begin{array}{l}\text { Who is primarily responsible } \\
\text { for approving or rejecting } \\
\text { proposals for new } \\
\text { developments in the City of } \\
\text { Toronto? }\end{array}$ & $\begin{array}{l}\text { (a) The mayor } \\
\text { (b) City planners } \\
\text { (c) City council [correct response] } \\
\text { (d) Ministry of Municipal Affairs and Housing } \\
\text { (e) None of the above } \\
\text { (f) Not sure }\end{array}$ & III \\
\hline 31. & $\begin{array}{l}\text { One of City Planning's jobs is } \\
\text { to develop strategic policies } \\
\text { and plans that say how the } \\
\text { City of Toronto should grow. }\end{array}$ & $\begin{array}{l}\text { (a) True [correct response] } \\
\text { (b) False } \\
\text { (c) Not sure }\end{array}$ & III \\
\hline 32. & $\begin{array}{l}\text { City Planning has the final } \\
\text { word on whether or not a new } \\
\text { proposed building project can } \\
\text { proceed. }\end{array}$ & $\begin{array}{l}\text { (a) True } \\
\text { (b) False [correct response] } \\
\text { (c) Not sure }\end{array}$ & III \\
\hline 33. & $\begin{array}{l}\text { City Planning } \\
\text { cannot specify exactly what } \\
\text { people or organizations move } \\
\text { into a building. }\end{array}$ & $\begin{array}{l}\text { (a) True [correct response] } \\
\text { (b) False } \\
\text { (c) Not sure }\end{array}$ & III \\
\hline 34. & $\begin{array}{l}\text { Money in the City of } \\
\text { Toronto’s parks budget can be } \\
\text { used to fund transit or housing } \\
\text { projects. }\end{array}$ & $\begin{array}{l}\text { (a) True } \\
\text { (b) False [correct response] } \\
\text { (c) Not sure }\end{array}$ & III \\
\hline 35. & $\begin{array}{l}\text { The City of Toronto has the } \\
\text { power to pass laws on all and } \\
\text { any matters it thinks are } \\
\text { appropriate to pass in the } \\
\text { public interest. }\end{array}$ & $\begin{array}{l}\text { (a) True } \\
\text { (b) False [correct response] } \\
\text { (c) Not sure }\end{array}$ & III \\
\hline 36. & $\begin{array}{l}\text { Do you know if there is an } \\
\text { active residents' association, } \\
\text { ratepayers' association or } \\
\text { other community group that }\end{array}$ & $\begin{array}{l}\text { (a) Yes, I know that there is/isn’t one } \\
\text { (b) No, I am not sure if there is/isn't one } \\
\text { (c) Sorry, I do not understand the question }\end{array}$ & III \\
\hline
\end{tabular}




\begin{tabular}{|l|l|l|l|}
\hline $\begin{array}{l}\text { represents your } \\
\text { neighbourhood? }\end{array}$ & *Additional comments & \\
\hline
\end{tabular}

\section{SECTION 5 - MESSAGES FROM CITY PLANNING}

This next section is about messages from City Planning that you might receive in the mail or see around town.

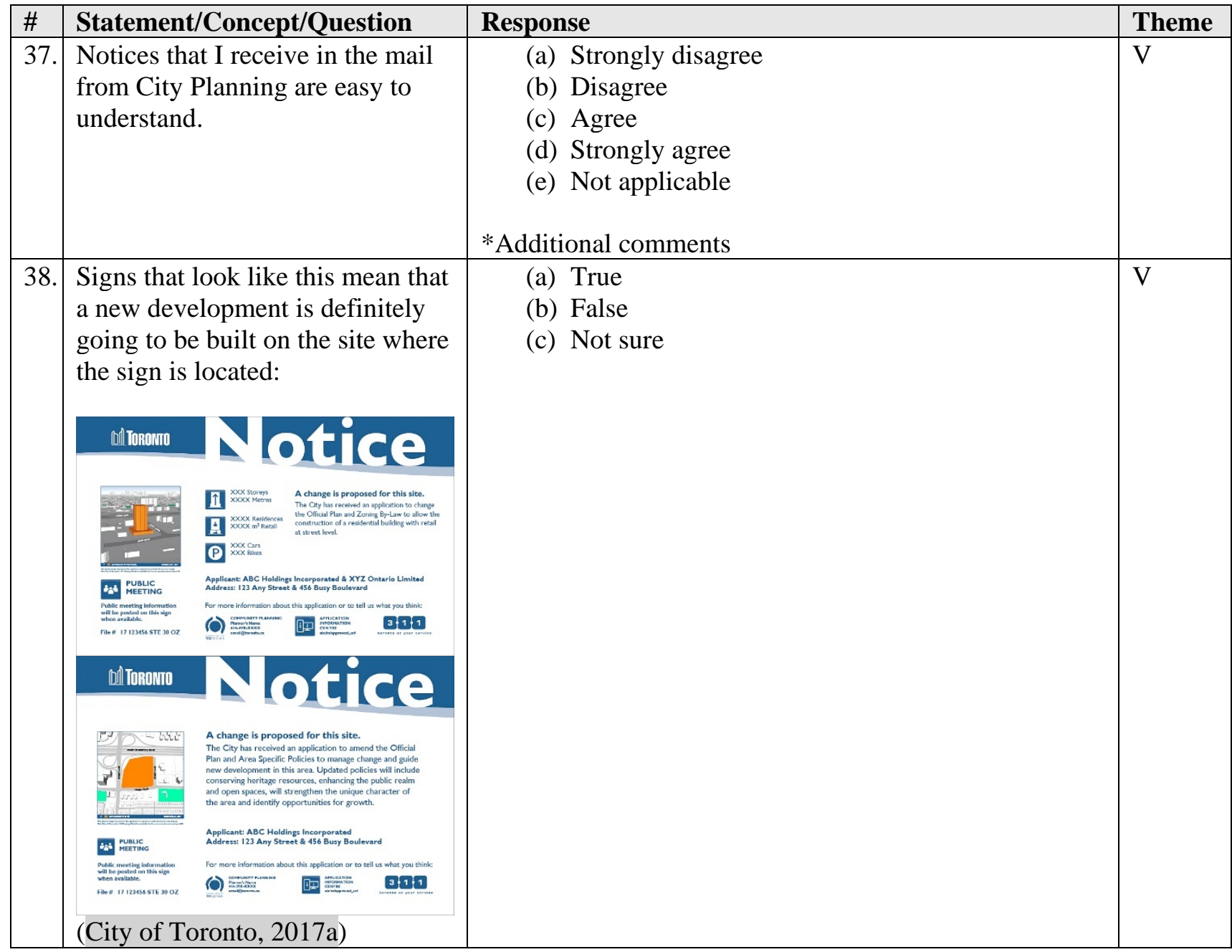

\section{SECTION 6 - KNOWING HOW TO DEAL WITH PLANNING MATTERS}

Almost done! This section is about how comfortable you are dealing with planning matters that might come up in your day-to-day life.

\begin{tabular}{|l|l|l|l|}
\hline$\#$ & Statement/Concept/Question & Response & Theme \\
\hline 39. & If a friend were to ask you what & (a) The zoning by-law amendment process & II \\
& process they must follow to build & (b) The minor variance process [Correct response] & \\
an addition to their house, what & $\begin{array}{l}\text { (c) The Official Plan amendment process } \\
\text { would you suggest they look into? }\end{array}$ & $\begin{array}{l}\text { (d) None of the above } \\
\text { (e) I have no idea }\end{array}$ & \\
\hline
\end{tabular}




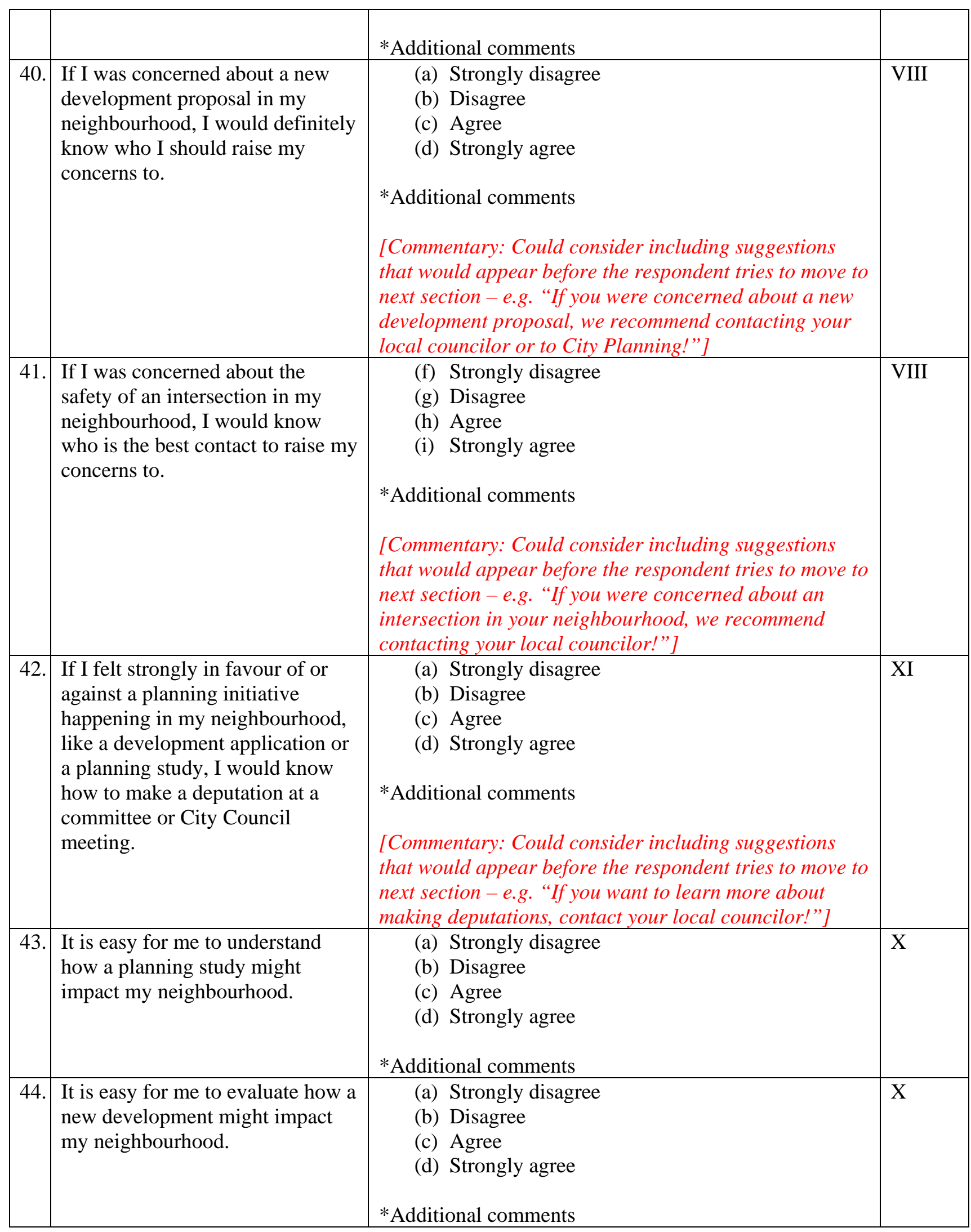




\begin{tabular}{|l|l|l|l|}
\hline 45. & I feel confident in my ability to & (a) Strongly disagree & VI \\
have a discussion about planning & (b) Disagree & & \\
issues with a city planner, & (c) Agree & & \\
developer or planning consultant. & (d) Strongly agree & & \\
& & *Additional comments & \\
\hline
\end{tabular}

\section{SECTION 7 - PERSONAL INFORMATION}

This is the last section. We are hoping for some information about you. This will help City Planning identify possible trends and make changes to how it engages with the public. All information that we collect will be kept completely anonymous.

\begin{tabular}{|c|c|c|}
\hline \# & Statement/Concept/Question & Response \\
\hline 1. & $\begin{array}{l}\text { What are the first three letters of your } \\
\text { postal code? }\end{array}$ & [Respondent to type out] \\
\hline 2. & What gender do you identify with? & $\begin{array}{l}\text { (a) Female } \\
\text { (b) Male } \\
\text { (c) Other } \\
\text { (d) Prefer not to disclose }\end{array}$ \\
\hline 3. & What is your age? & [Respondent to type out] \\
\hline 4. & $\begin{array}{l}\text { What language do you speak most often } \\
\text { at home? }\end{array}$ & $\begin{array}{l}\text { (a) English } \\
\text { (b) French } \\
\text { (c) Arabic } \\
\text { (d) Chinese - Cantonese } \\
\text { (e) German } \\
\text { (f) Italian } \\
\text { (g) Punjabi } \\
\text { (h) Russian } \\
\text { (i) Urdu } \\
\text { (j) Vietnamese } \\
\text { (k) Other (Please specify) }\end{array}$ \\
\hline 5. & $\begin{array}{l}\text { What is the highest level of education that } \\
\text { you have completed? }\end{array}$ & $\begin{array}{l}\text { (a) Elementary school } \\
\text { (b) High school (secondary school) diploma or } \\
\text { equivalent } \\
\text { (c) Registered Apprenticeship or other trades } \\
\text { certificate or diploma } \\
\text { (d) College, CEGEP or other non-university } \\
\text { certificate or diploma } \\
\text { (e) University certificate, diploma or degree } \\
\text { (Bachelors or Masters) } \\
\text { (f) University certificate, diploma or degree (PhD, } \\
\text { Post-doctoral or Professional) } \\
\text { (g) Other (Please specify) }\end{array}$ \\
\hline 6. & $\begin{array}{l}\text { What is your annual household income } \\
\text { before taxes? }\end{array}$ & $\begin{array}{l}\text { (a) Under } \$ 5,000 \\
\text { (b) } \$ 5,000-\$ 19,999 \\
\text { (c) } \$ 20,000-\$ 39,999 \\
\text { (d) } \$ 40,000-\$ 59,999 \\
\text { (e) } \$ 60,000-\$ 79,999 \\
\text { (f) } \$ 80,000-\$ 99,999\end{array}$ \\
\hline
\end{tabular}




\begin{tabular}{|c|c|c|}
\hline & & $\begin{array}{l}\text { (g) } \$ 100,000-\$ 119,999 \\
\text { (h) } \$ 120,000-\$ 139,999 \\
\text { (i) } \$ 140,000 \text { and over } \\
\text { (j) Prefer not to disclose }\end{array}$ \\
\hline 7. & $\begin{array}{l}\text { Do you have experience (current or } \\
\text { previous) studying or working in a field } \\
\text { related to urban planning? }\end{array}$ & $\begin{array}{l}\text { (a) Yes } \\
\text { (b) No } \\
\text { (c) Unsure } \\
\end{array}$ \\
\hline 8. & $\begin{array}{l}\text { Are you, or have you ever been, a } \\
\text { member of a residents' or community } \\
\text { association? }\end{array}$ & $\begin{array}{l}\text { (a) Yes } \\
\text { (b) No } \\
\text { (c) Unsure } \\
\end{array}$ \\
\hline 9 . & Any other comments? & [Respondent to provide comments.] \\
\hline
\end{tabular}

Thank you again for taking the time to complete this planning literacy survey! We look forward to learning what you know about planning, and where we can do better.

If you have any questions about the survey, feel free to contact [name, position] at [phone number] or [email]. 